\title{
Unsymmetrical bidentate ligands of $\alpha$-aminoaldimines leading to sterically controlled selectivity of geometrical isomerism in square planar coordination $\uparrow$
}

\author{
Jen-Jeh Lee, Feng-Zhao Yang, Ya-Fan Lin, Ya-Chun Chang, Kuo-Hsuan Yu, Mu-Chieh Chang, \\ Gene-Hsiang Lee, Yi-Hung Liu, Yu Wang, Shiuh-Tzung Liu and Jwu-Ting Chen*
}

Received 4th April 2008, Accepted 18th July 2008

First published as an Advance Article on the web 16th September 2008

DOI: 10.1039/b805674a

New $\alpha$-aminoaldimines with the formula of $\mathrm{Et}_{2} \mathrm{NCMe}_{2} \mathrm{CH}=\mathrm{NR}\left(\mathrm{R}={ }^{\mathrm{i}} \mathrm{Pr},{ }^{\mathrm{t}} \mathrm{Bu}, \mathrm{Ph}\right)$ and their dichloro or diacetato complexes of $\mathrm{Ni}, \mathrm{Pd}, \mathrm{Pt}$ are prepared and structurally characterized. A nickel complex is in a distorted tetrahedral configuration, and the Pd and Pt complexes (4-6) are of square planar form. The $\alpha$-aminoaldimines can chelate to the metal in a $C_{2}$-unsymmetric bidentate motif through the hetero functionalities of amine and imine, which show comparable trans influence. Square planar organometallic palladium derivatives bearing $\alpha$-aminoaldimines, including Pd-methyl, Pd-acetyl, and Pd- $\left(\eta^{2}\right.$-acetylnorboryl) (7-10), are also synthesized. The latter two species are a result of CO-insertion into $\mathrm{Pd}$-methyl complexes and ensuing norbornene-insertion, respectively. The geometrical isomerism is found in the trans configuration in most studied cases. Such a stereoselectivity results from the thermodynamic stability governed predominantly by steric control. The stereoselectivity is also supported by DFT calculations.

\section{Introduction}

New auxiliary ligands often bring new chemical features to coordination chemistry. The bidentate ligands with hybrid hard and soft donors have been acquiring enormous attention, because they are anticipated to confer different electronic and steric effects to the metal center as well as reactivity of the complexes. ${ }^{1}$ Some unsymmetrical bidentate ligands contain the same donor atom in hybrid functionalities. ${ }^{2}$ Among them, those that coordinate through the functionalities of amine and imine are rarely studied. ${ }^{3}$ Still, a few cases have proved to be useful for catalysis. ${ }^{4}$ Others are found to be important to bio-functions. ${ }^{5}$ Amino acids which can coordinate with metal through two hard groups of amine and carboxylate simultaneously can serve as natural unsymmetrical bidentate ligands. ${ }^{6}$ The $\alpha$-aminoaldimines, which are imino derivatives of amino acids, may be expected to provide chelation of non- $C_{2}$-symmetry through the two nitrogen donor atoms of the hetero functionalities of amine and imine. Such ligands might be suitable candidates for the examination of the individual power of electronic and steric influences in their coordination chemistry, particularly in the square planar mode.

There are at least several distinguishable aspects between amine and imine that are worthy of note. Amine is a typical $\sigma$-base containing a nitrogen donor atom of $\mathrm{sp}^{3}$ configuration, often with bond angles of less than $110^{\circ}$. On the other hand, imine has both $\sigma$-donating and $\pi$-accepting character and has a nitrogen donor atom of $\mathrm{sp}^{2}$ configuration, and gives significantly larger bond angles of around $120^{\circ}$ with the adjacent ligand. In the square planar coordinating motif as shown in Chart $1, \alpha$-aminoaldimines

Department of Chemistry, National Taiwan University, No 1, Section 4, Roosevelt Road, Taipei, 106, Taiwan.E-mail: jtchen@ntu.edu.tw; Fax: +886-22363-6359; Tel: +886-2-3366-1659

$\dagger$ CCDC reference numbers 682281, 683783-683791 (3c, 4a, 4c, 5b, 5c, 6c, $7 \mathbf{a}, 7 \mathbf{c}, 8 \mathbf{c}$ and 10c). For crystallographic data in CIF or other electronic format see DOI: $10.1039 / \mathrm{b} 805674 \mathrm{a}$

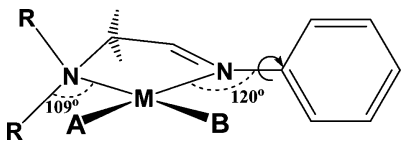

Chart 1 Square planar configuration with $\alpha$-aminoaldimines.

constitute a non-planar five-membered ring with the metal ion. The amine holds two substituents, but the imine may only have one. The imino substituent can rotate along the $\mathrm{N}-\mathrm{C}$ bond which lies in the molecular plane. ${ }^{7}$ In contrast, the amino substituents are in tetrahedral fashion that directs out of molecular plane and potentially can provide an asymmetric environment. ${ }^{8}$ Therefore, the coordination sites of $\mathrm{A}$ and $\mathrm{B}$ are expected to experience individual influence from the amine and imine functionalities.

In this article we report the synthesis and structures of the dichloro, diacetato, and some organometallic complexes of group 10 transition metals that bear new ligands of $\alpha$-aminoaldimines. In the dichloro and diacetato species, the functionalities of amine and imine demonstrate comparable trans influence. In the organometallic derivatives, these unsymmetrical auxiliary ligands lead to geometrical stereoselectivity and geometrical isomerism that are attributed to the sterically controlled thermodynamic stability.

\section{Results and discussion}

\section{Synthesis and spectroscopic characterization}

The starting material, 2-bromo-2-methylpropanal (1), ${ }^{9}$ was prepared by a reaction of bromine-1,4-dioxane and 2-methylpropanal in diethyl ether. The reaction slurry was constantly stirred till the disappearance of the orange color. The reaction solution was stirred for another $10 \mathrm{~min}$, then extracted with ice-cold water. The resulting solution was dried with $\mathrm{MgSO}_{4}$, and ether was removed 
on a rotary evaporator. The brominated derivative $\mathbf{1}$ was usually ready for immediate use in the ensuing reaction.

There are two potential electrophilic sites in 2-bromo-2methylpropanal (1). The reaction of $\mathbf{1}$ with secondary amine only leads to the substitution of bromine, presumably by radical-nucleophilic substitution, $\mathrm{S}_{\mathrm{RN}} 1$, mechanism. ${ }^{10}$ The new $\alpha$-aminoaldimines in the form of $\mathrm{Et}_{2} \mathrm{NCMe}_{2} \mathrm{CH}=\mathrm{NR}\left(\mathrm{R}={ }^{\mathrm{i}} \mathrm{Pr}\right.$ (2a), $\left.{ }^{\mathrm{t}} \mathrm{Bu}(\mathbf{2 b}), \mathrm{Ph}(\mathbf{2 c})\right)$ are synthesized first by substitution of diethylamine for bromine in $\mathbf{1}$, and followed by condensation using primary amine or aniline, respectively, as shown in Scheme 1. The products are collected as viscous colorless liquids in good yields by means of distillation under reduced pressure. The structures of the new derivatives of $\alpha$-aminoaldimines are mainly determined by spectroscopic methods.

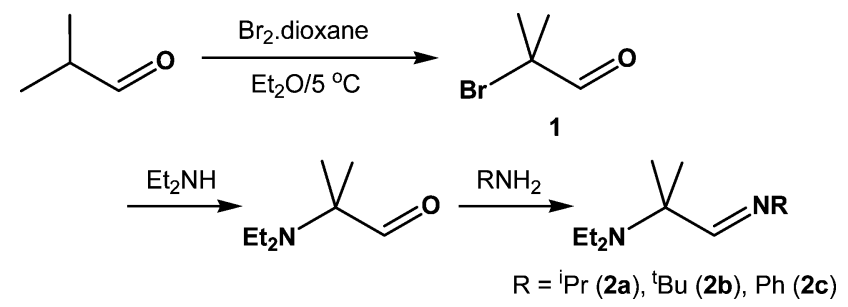

Scheme 1 Synthesis of $\alpha$-aminoaldimines.

Compounds $\mathbf{2 a}, \mathbf{2 b}$ or $\mathbf{2 c}$ can serve as bidentate ligands with hybrid donor functionalities of amine and imine. The substitution reactions of $\mathbf{2 a}, \mathbf{2 b}$ or $\mathbf{2 c}$ with $(\mathrm{PhCN})_{2} \mathrm{MCl}_{2}(\mathrm{M}=\mathrm{Pd}, \mathrm{Pt})$ leads to the neutral amine-imine complexes in the form of $\left[\mathrm{Et}_{2} \mathrm{NCMe}_{2} \mathrm{CH}=\mathrm{NR}\right] \mathrm{MCl}_{2}\left(\mathrm{M}=\mathrm{Pd}, \mathrm{R}={ }^{\mathrm{i}} \operatorname{Pr}(\mathbf{4 a}), \mathrm{Ph}(\mathbf{4 c}) ; \mathrm{M}=\right.$ $\left.\mathrm{Pt}, \mathrm{R}={ }^{\mathrm{t}} \mathrm{Bu}(\mathbf{5 b}), \mathrm{Ph}(\mathbf{5 c})\right)$, as shown in Scheme 2. The yields for the palladium complexes are excellent, but relatively poor for the platinum complexes. Similar reaction of $\mathbf{2} \mathbf{c}$ and $(\mathrm{DME}) \mathrm{NiCl}_{2}(\mathrm{DME}=$ 1,2-dimethoxyethane) generate $\left[\mathrm{Et}_{2} \mathrm{NCMe}_{2} \mathrm{CH}=\mathrm{NPh}\right] \mathrm{NiCl}_{2}(3 \mathrm{c})$. Recrystallization of the violet inorganic product from $\mathrm{CH}_{2} \mathrm{Cl}_{2}-$ $\mathrm{Et}_{2} \mathrm{O}$ gives $62 \%$ yields and single crystals. The broadened NMR spectra of $3 \mathbf{c}$ implicates a paramagnetic electronic configuration and tetrahedral molecular geometry.

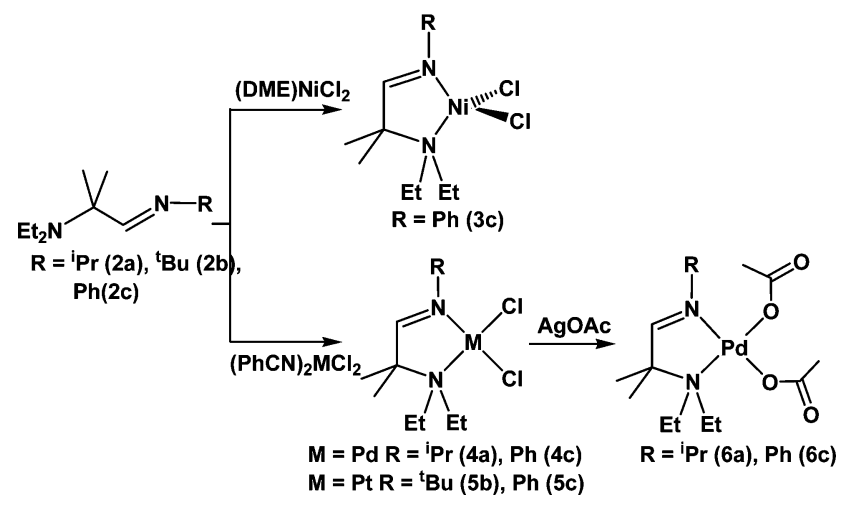

Scheme 2 Synthesis of dichloro and diacetato complexes of $\mathrm{Ni}, \mathrm{Pd}$, or Pt.

The distinct shift of the imino hydrogen signals in the ${ }^{1} \mathrm{H}$ NMR spectra and the imino carbon in the ${ }^{13} \mathrm{C}$ NMR spectra for the palladium and platinum complexes indicate the coordination mode of the ligand. The diastereotopic hydrogens of the amino methylene group, shown by the ${ }^{1} \mathrm{H}$ NMR, also support the tetrahedral configuration in the coordinating mode of amine. ${ }^{11}$ Treating $4 \mathbf{a}$ or $\mathbf{4} \mathbf{c}$ with double molar amounts of silver acetate gives rise to the formation of diacetato complexes in the form of $\left[\mathrm{Et}_{2} \mathrm{NCMe}_{2} \mathrm{CH}=\mathrm{NR}\right] \mathrm{Pd}(\mathrm{OAc})_{2}\left(\mathrm{R}={ }^{i} \mathrm{Pr}(\mathbf{6 a}), \mathrm{Ph}(\mathbf{6 c})\right)$. The $\mathrm{C}=\mathrm{O}$ stretching frequencies below $1700 \mathrm{~cm}^{-1}$ appear to be lower than the free acetates, and comparable to the coordinating fashion. ${ }^{12}$ The $C_{2}$-unsymmetrical ligand results in the differentiation for the two acetato ligands. The two acetyloxy methyl groups in $\mathbf{6 a}$ have close resonances in the ${ }^{1} \mathrm{H}$ NMR spectrum, implying small electronic difference between the amine and imine functionalities. For $\mathbf{6 c}$, there is only one carbonyl carbon identified in the ${ }^{13} \mathrm{C}$ NMR spectrum. However, two acetyloxy methyl signals in the ${ }^{1} \mathrm{H}$ and ${ }^{13} \mathrm{C}$ NMR spectra are observed. One is particularly upfield, presumably due to the ring current from the phenyl group on the cis imine.

Neutral organometallic complexes in the formula of $\left[\mathrm{Et}_{2} \mathrm{NCMe}_{2} \mathrm{CH}=\mathrm{NR}\right] \mathrm{Pd}(\mathrm{Me}) \mathrm{Cl}\left(\mathrm{R}={ }^{i} \mathrm{Pr}(\mathbf{7 a}), \mathrm{Ph}(\mathbf{7 c})\right)$ could be prepared either by substitution of $\alpha$-aminoaldimines for COD $\left(1,4\right.$-cyclooctadiene) in $(\mathrm{COD}) \mathrm{Pd}(\mathrm{Me}) \mathrm{Cl}^{13}{ }^{13}$ or by transmetallation using an organotin reagent ${ }^{14}$ with $\left[\mathrm{Et}_{2} \mathrm{NCMe}_{2} \mathrm{CH}=\mathrm{NR}\right] \mathrm{PdCl}_{2}$ (Scheme 3). The NMR data indicate that a single geometrical isomer is formed selectively. The Pd-bound methyl group of $7 \mathbf{c}$ appears substantially upfield than that of $7 \mathbf{a}, \delta 0.46 v s$. 0.73 , implicating that methyl is likely cis to imine, and thus influenced by the ring current from the imino phenyl group. Chloride abstraction from $7 \mathbf{a}$ or $7 \mathbf{c}$ by silver triflate in acetonitrile results in the cationic species $\left\{\left[\mathrm{Et}_{2} \mathrm{NCMe}_{2} \mathrm{CH}=\mathrm{NR}\right] \operatorname{PdMe}(\mathrm{NCMe})\right\} \mathrm{OTf}\left(\mathrm{R}={ }^{\mathrm{i}} \operatorname{Pr}(\mathbf{8 a})\right.$, $\mathrm{Ph}(\mathbf{8 c}))$. The stereochemistry of the trans isomerism is considered to be retained, since the Pd-bound methyl group in the NMR spectra for $\mathbf{8 a}$ and $\mathbf{8 c}$ resemble those for $7 \mathbf{a}$ and $7 \mathbf{c}$, respectively.

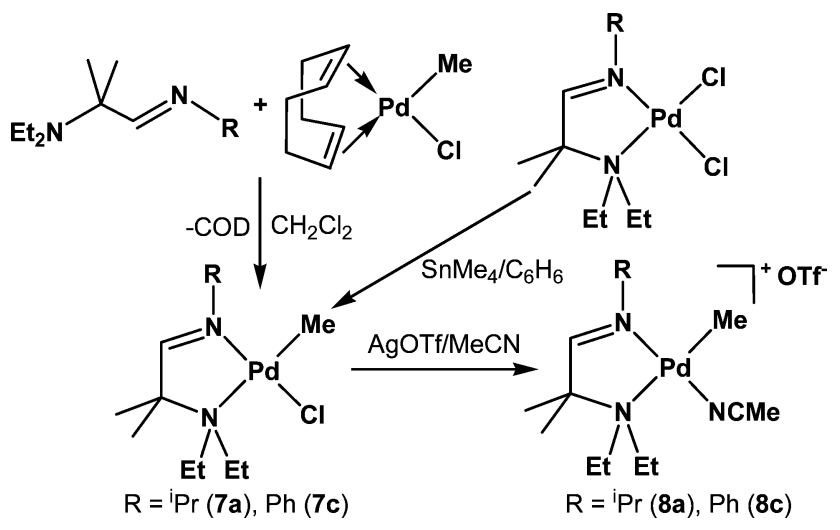

Scheme 3 Synthesis of methylpalladium complexes.

Allowing $\mathrm{CO}$ to bubble through the solution of $7 \mathbf{a}$ or $7 \mathbf{c}$ readily results in a single product of neutral acetylpalladium complex $9 \mathbf{a}$ or $9 \mathrm{c}$, respectively. A characteristic acyl $\mathrm{CH}_{3}$ signal is at $\delta 2.44$ in the ${ }^{1} \mathrm{H}$ NMR; and an acyl carbonyl is at $\delta 226.4$ in the ${ }^{13} \mathrm{C}$ NMR for 9a. For 9c, the corresponding data are $\delta 2.10$ and $\delta$ 223.0, respectively. Chloride abstraction from 8a or $\mathbf{8 c}$ using silver triflate in acetonitrile with the presence of norbornene leads to olefin insertion, yielding cationic acetylnorbornyl complexes 10a or 10c, respectively. Complexes 10a and 10c may alternatively be achieved from 8a and $\mathbf{8 c}$, respectively, with the presence of carbon monoxide and norbornene together, as illustrated in Scheme 4. The carbonyl stretching signals of low infrared frequencies, $1608 \mathrm{~cm}^{-1}$ for 10a and $1605 \mathrm{~cm}^{-1}$ for 10c, suggest that a coordinating mode 


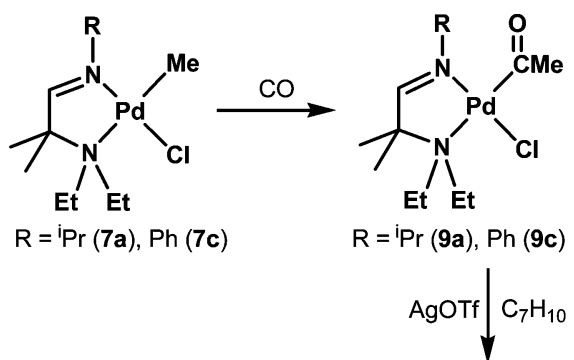<smiles>[R]Pc1ccccc1</smiles>

Scheme 4 CO and norbornene insertion of methylpalladium complexes.

through acyl oxygen might occur, as observed in many analogous prior cases. ${ }^{15}$ It is noted again that some NMR resonances corresponding to the norbornyl hydrogen in $\mathbf{1 0 c}$ are in the upfield region compared to $\mathbf{1 0 a}$. It is thus thought that the norbornyl group is cis to the imino functionality.

\section{X-Ray structural analysis}

Single crystals of $3 \mathbf{c}, 4 \mathbf{a}, 4 \mathbf{c}, 5 \mathbf{b}, 5 \mathbf{c}, 6 \mathbf{c}, 7 \mathbf{a}, 7 \mathbf{c}, 8 \mathbf{c}$ and $10 \mathrm{c}$ that are suitable for X-ray diffractions have been obtained. Crystallographic analyses provide unequivocal evidence for the molecular structures of these complexes which bear unsymmetrical amineimine bidentates. The crystal data are listed in Table 1, and the selected bond lengths and bond angles are collected in Table 2.

In Fig. 1, the ORTEP drawing of complex $\mathbf{3 c}$ is in a distorted tetrahedral configuration which explains its paramagnetism suggested by the broadened NMR signals. The amine-imine complexes of dichloropalladium, dichloroplatinum, and diacetatopalladium are all square planar. The representative ORTEP drawings of $\mathbf{4 a}, \mathbf{4 c}, \mathbf{5 b}$ and $\mathbf{6 c}$ are shown in Fig. 2 and 3; 8c and 10c are in Fig. 4 and 5, respectively.

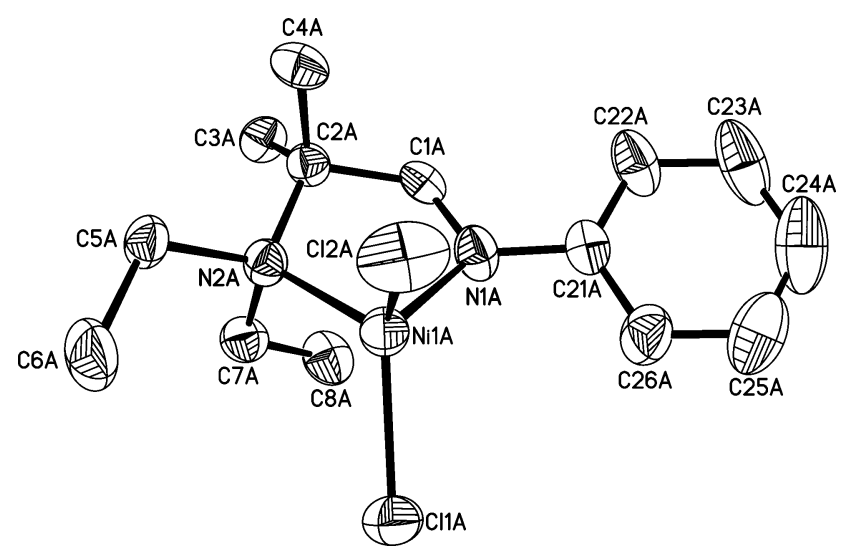

Fig. 1 ORTEP drawing of $\left[\mathrm{Et}_{2} \mathrm{NCMe}_{2} \mathrm{CH}=\mathrm{NPh}\right] \mathrm{NiCl}_{2}(3 \mathrm{c})$. All hydrogen atoms are omitted for clarity.

By viewing the data of $3 \mathbf{c}$ in Table 2, the distance of the Ni$\mathrm{N} 2\left(\mathrm{sp}^{3}\right)$ bond is longer than the $\mathrm{Ni}-\mathrm{N} 1\left(\mathrm{sp}^{2}\right)$ bond $(2.045 \AA$ vs.
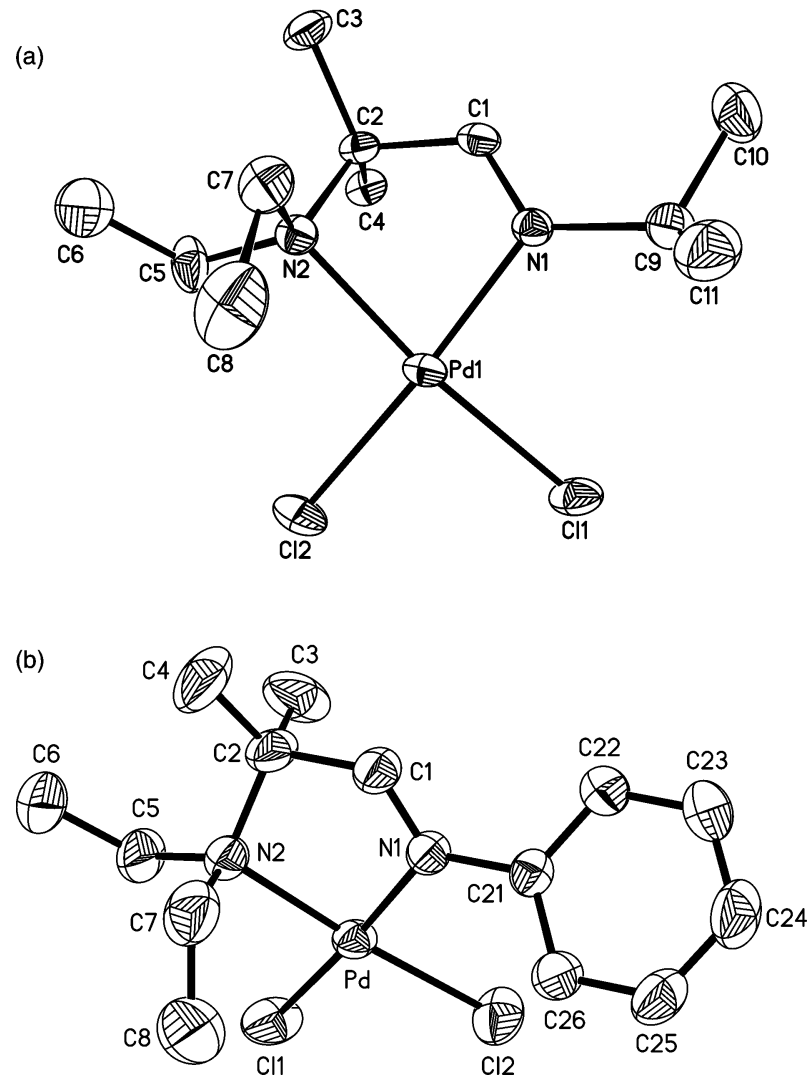

Fig. 2 ORTEP drawings of (a) $\left[\mathrm{Et}_{2} \mathrm{NCMe}_{2} \mathrm{CH}=\mathrm{N}^{\mathrm{i}} \mathrm{Pr}\right] \mathrm{PdCl}_{2}$ (4a), and (b) $\left[\mathrm{Et}_{2} \mathrm{NCMe}_{2} \mathrm{CH}=\mathrm{NPh}\right] \mathrm{PdCl}_{2}$ (4c). All hydrogen atoms are omitted for clarity.

$1.979 \AA$ ); and the distance of the amino $\mathrm{C} 2-\mathrm{N} 2$ bond is longer than the imino $\mathrm{C} 1-\mathrm{N} 1$ bond $(1.520 \AA$ vs. $1.297 \AA$ ), as expected. The $\mathrm{N} 1-\mathrm{Ni}-\mathrm{N} 2$ angle is $83.5(1)^{\circ}$, nearly the same as that in Brookhart's diimine catalysts. ${ }^{16}$ The $\mathrm{Cl} 1-\mathrm{Ni}-\mathrm{Cl} 2$ angle is $115.65(5)^{\circ}$. In other $\mathrm{Pd}$ or $\mathrm{Pt}$ complexes of square planar geometry, the differences between the $\mathrm{Pd}-\mathrm{N} 1$ bond and $\mathrm{Pd}-\mathrm{N} 2$ bond are slightly larger than that in 3c (about $0.1 \AA$ vs. $0.07 \AA$ ). The imino $\mathrm{C} 1-\mathrm{N} 1$ bonds are generally shorter (about $1.27 \AA$ vs. $1.30 \AA$ ) and the N1-M-N2 angles are generally smaller (about $80^{\circ}$ vs. $84^{\circ}$ ) in $\mathbf{4 a}, \mathbf{4 c}, \mathbf{5 b}, \mathbf{5 c}$ and $\mathbf{6 c}$ than in $\mathbf{3 c}$. It is noted that in the square planar complexes of $4 a, 4 c, 5 b, 5 c$, and $\mathbf{6 c}$ the distances of two $\mathrm{M}-\mathrm{Cl}$ or of two $\mathrm{Pd}-\mathrm{O}$ bonds are all rather comparable, with the difference being less than about $0.01 \AA$. In the general sense, this phenomenon indicates that the amino group and the imino group hardly show significant difference in trans influence. ${ }^{17}$

The structures of organometallic species $7 \mathbf{a}, 7 \mathbf{c}, 8 \mathbf{c}$ and $10 \mathbf{c}$ are all in the trans configuration, i.e. the metal-carbon bond is trans to the amino nitrogen, no matter if the substituent on the imino nitrogen is isopropyl or the phenyl group. Complex 10c indicates that the norbornene insertion into the $\mathrm{Pd}$-acyl bond takes place in the sole $s y n /$ exo-fashion. ${ }^{18}$

Further looking into the bond parameters as summarized in Table 3, a few trends may be noticed. The $\mathrm{Pd}-\mathrm{N} 2$ bonds in the organometallic derivatives are substantially longer $(>0.1 \AA)$ than those in the dichloro derivatives. And, the differences between the $\mathrm{Pd}-\mathrm{N} 1$ and $\mathrm{Pd}-\mathrm{N} 2$ bonds are larger in the organometallic complexes than in the dichloro complexes $(0.2 \AA$ vs. $0.1 \AA)$. This 


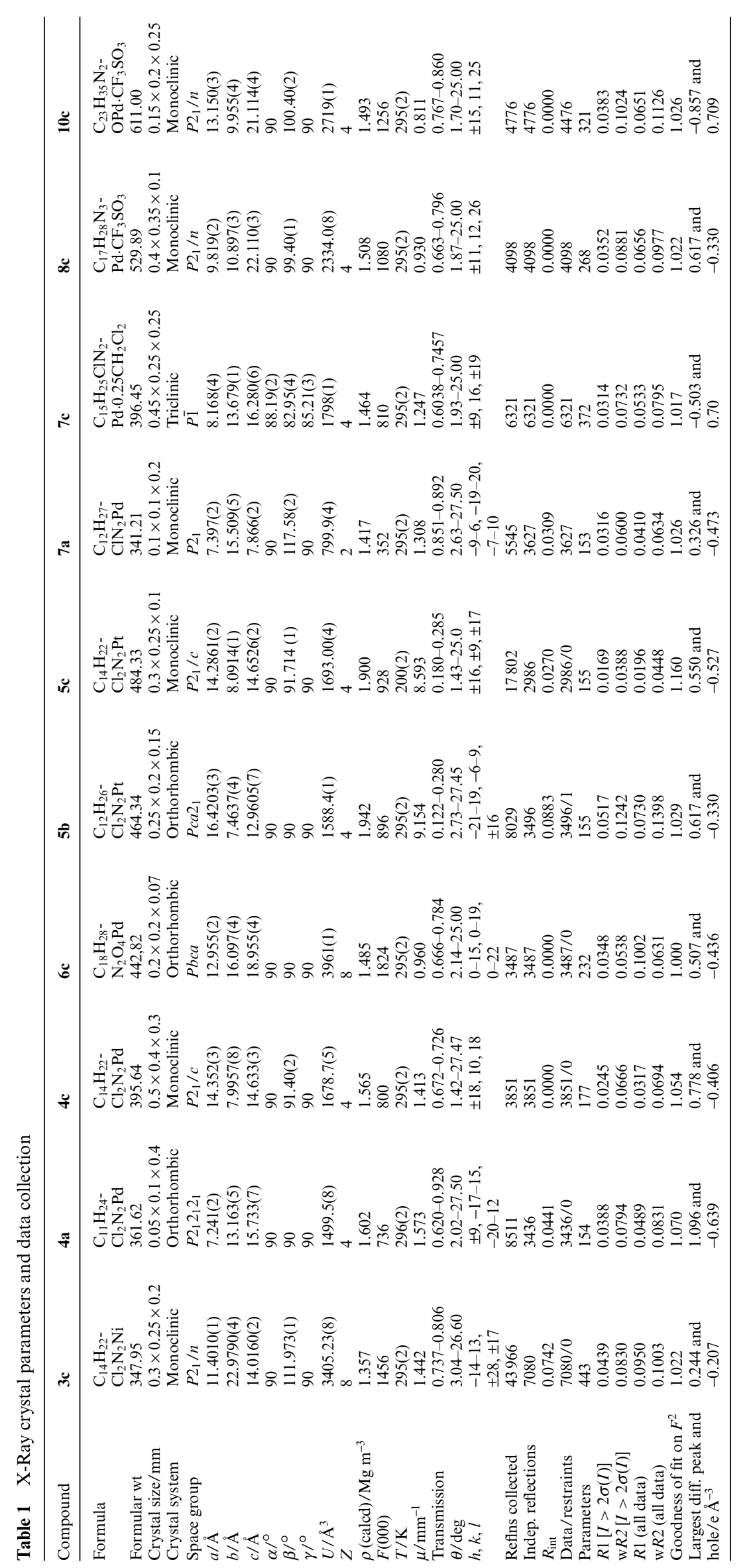


Table 2 Selected bond distances $(\AA)$ and angles $\left({ }^{\circ}\right)$

\begin{tabular}{|c|c|c|c|c|c|c|c|}
\hline \multicolumn{8}{|c|}{$\left[\mathrm{Et}_{2} \mathrm{NCMe}_{2} \mathrm{CH}=\mathrm{NPh}\right] \mathrm{NiCl}_{2}(\mathbf{3 c})$} \\
\hline $\mathrm{Ni}-\mathrm{N} 1$ & $1.979(3)$ & $\mathrm{Ni}-\mathrm{N} 2$ & $2.045(2)$ & $\mathrm{Ni}-\mathrm{Cll}$ & $2.217(1)$ & $\mathrm{Ni}-\mathrm{Cl} 2$ & $2.206(1)$ \\
\hline $\mathrm{N} 1-\mathrm{C} 1$ & $1.297(8)$ & $\mathrm{N} 2-\mathrm{C} 2$ & $1.520(5)$ & $\mathrm{C} 1-\mathrm{C} 2$ & $1.498(9)$ & $\mathrm{N} 1-\mathrm{C} 21$ & $1.428(4)$ \\
\hline $\mathrm{N} 2-\mathrm{C} 5$ & $1.482(6)$ & $\mathrm{N} 2-\mathrm{C} 7$ & $1.531(6)$ & & & & \\
\hline $\mathrm{N} 1-\mathrm{Ni}-\mathrm{N} 2$ & $83.5(1)$ & $\mathrm{C} 11-\mathrm{Ni}-\mathrm{Cl} 2$ & $115.65(5)$ & $\mathrm{Ni}-\mathrm{N} 1-\mathrm{C} 1$ & $112.8(4)$ & & \\
\hline $\mathrm{Ni}-\mathrm{N} 2-\mathrm{C} 2$ & $106.5(2)$ & $\mathrm{N} 1-\mathrm{C} 1-\mathrm{C} 2$ & $120.4(6)$ & $\mathrm{N} 2-\mathrm{C} 2-\mathrm{C} 1$ & $107.4(4)$ & & \\
\hline $\mathrm{C} 5-\mathrm{N} 2-\mathrm{Ni}$ & $112.6(3)$ & $\mathrm{C} 7-\mathrm{N} 2-\mathrm{Ni}$ & $107.2(3)$ & $\mathrm{C} 21-\mathrm{N} 1-\mathrm{Ni}$ & $125.6(2)$ & & \\
\hline \multicolumn{8}{|c|}{$\left[\mathrm{Et}_{2} \mathrm{NCMe}_{2} \mathrm{CH}=\mathrm{N}^{\mathrm{i}} \mathrm{Pr}\right] \mathrm{PdCl}_{2}(\mathbf{4 a})$} \\
\hline $\mathrm{Pd}-\mathrm{N} 1$ & $2.028(3)$ & $\mathrm{Pd}-\mathrm{N} 2$ & $2.126(4)$ & $\mathrm{Pd}-\mathrm{Cl} 1$ & $2.314(1)$ & $\mathrm{Pd}-\mathrm{Cl} 2$ & $2.297(1)$ \\
\hline $\mathrm{N} 1-\mathrm{C} 1$ & $1.263(6)$ & $\mathrm{N} 2-\mathrm{C} 2$ & $1.534(6)$ & $\mathrm{C} 1-\mathrm{C} 2$ & $1.493(6)$ & $\mathrm{N} 1-\mathrm{C} 9$ & $1.477(6)$ \\
\hline $\mathrm{N} 2-\mathrm{C} 5$ & $1.493(7)$ & $\mathrm{N} 2-\mathrm{C} 7$ & $1.510(6)$ & & & & \\
\hline N1-Pd-N2 & $79.78(1)$ & $\mathrm{Cl} 1-\mathrm{Pd}-\mathrm{Cl} 2$ & $89.31(6)$ & $\mathrm{Pd}-\mathrm{N} 1-\mathrm{C} 1$ & $111.8(3)$ & & \\
\hline $\mathrm{Pd}-\mathrm{N} 2-\mathrm{C} 2$ & $100.9(2)$ & $\mathrm{N} 1-\mathrm{C} 1-\mathrm{C} 2$ & $120.9(4)$ & $\mathrm{N} 2-\mathrm{C} 2-\mathrm{C} 1$ & $105.2(3)$ & & \\
\hline $\mathrm{C} 5-\mathrm{N} 2-\mathrm{Pd}$ & $115.9(3)$ & $\mathrm{C} 7-\mathrm{N} 2-\mathrm{Pd}$ & $107.6(3)$ & C9-N1-Pd & $124.8(3)$ & & \\
\hline \multicolumn{8}{|c|}{$\left[\mathrm{Et}_{2} \mathrm{NCMe}_{2} \mathrm{CH}=\mathrm{NPh}\right] \mathrm{PdCl}_{2}(\mathbf{4 c})$} \\
\hline $\mathrm{Pd}-\mathrm{N} 1$ & $2.026(2)$ & $\mathrm{Pd}-\mathrm{N} 2$ & $2.115(2)$ & $\mathrm{Pd}-\mathrm{Cl1}$ & $2.2822(7)$ & $\mathrm{Pd}-\mathrm{Cl} 2$ & $2.2947(8)$ \\
\hline $\mathrm{N} 1-\mathrm{C} 1$ & $1.268(3)$ & $\mathrm{N} 2-\mathrm{C} 2$ & $1.528(3)$ & $\mathrm{C} 1-\mathrm{C} 2$ & $1.507(3)$ & $\mathrm{N} 1-\mathrm{C} 21$ & $1.435(3)$ \\
\hline $\mathrm{N} 2-\mathrm{C} 5$ & $1.505(3)$ & $\mathrm{N} 2-\mathrm{C} 7$ & $1.517(4)$ & & & & \\
\hline $\mathrm{N} 1-\mathrm{Pd}-\mathrm{N} 2$ & $80.03(8)$ & $\mathrm{Cl1}-\mathrm{Pd}-\mathrm{Cl} 2$ & $88.61(3)$ & $\mathrm{Pd}-\mathrm{N} 1-\mathrm{C} 1$ & $112.9(2)$ & & \\
\hline $\mathrm{Pd}-\mathrm{N} 2-\mathrm{C} 2$ & $103.0(2)$ & $\mathrm{N} 1-\mathrm{C} 1-\mathrm{C} 2$ & $120.4(2)$ & $\mathrm{N} 2-\mathrm{C} 2-\mathrm{C} 1$ & $105.4(2)$ & & \\
\hline $\mathrm{C} 5-\mathrm{N} 2-\mathrm{Pd}$ & $112.58(2)$ & C7-N2-Pd & $106.5(2)$ & $\mathrm{C} 21-\mathrm{N} 1-\mathrm{Pd}$ & $127.2(2)$ & & \\
\hline \multicolumn{8}{|c|}{$\left[\mathrm{Et}_{2} \mathrm{NCMe}_{2} \mathrm{CH}=\mathrm{N}^{\mathrm{t}} \mathrm{Bu}\right] \mathrm{PtCl}_{2}(\mathbf{5} \mathbf{b})$} \\
\hline $\mathrm{Pt}-\mathrm{N} 1$ & $2.03(1)$ & $\mathrm{Pt}-\mathrm{N} 2$ & $2.12(1)$ & $\mathrm{Pt}-\mathrm{Cl} 1$ & $2.310(4)$ & $\mathrm{Pt}-\mathrm{Cl} 2$ & $2.304(4)$ \\
\hline $\mathrm{N} 1-\mathrm{C} 1$ & $1.31(2)$ & $\mathrm{N} 2-\mathrm{C} 2$ & $1.54(2)$ & $\mathrm{C} 1-\mathrm{C} 2$ & $1.47(2)$ & $\mathrm{N} 1-\mathrm{C} 9$ & $1.50(2)$ \\
\hline $\mathrm{N} 2-\mathrm{C} 5$ & $1.51(2)$ & $\mathrm{N} 2-\mathrm{C} 7$ & $1.52(2)$ & & & & \\
\hline $\mathrm{N} 1-\mathrm{Pt}-\mathrm{N} 2$ & $80.1(5)$ & $\mathrm{Cl} 1-\mathrm{Pt}-\mathrm{Cl} 2$ & $84.8(2)$ & $\mathrm{Pt}-\mathrm{N} 1-\mathrm{C} 1$ & $112(1)$ & & \\
\hline $\mathrm{Pt}-\mathrm{N} 2-\mathrm{C} 2$ & $103(7)$ & $\mathrm{N} 1-\mathrm{C} 1-\mathrm{C} 2$ & $121(1)$ & $\mathrm{N} 2-\mathrm{C} 2-\mathrm{C} 1$ & $106(1)$ & & \\
\hline $\mathrm{C} 5-\mathrm{N} 2-\mathrm{Pt}$ & $111.3(8)$ & $\mathrm{C} 7-\mathrm{N} 2-\mathrm{Pt}$ & $109(1)$ & C9-N1-Pt & $128.6(8)$ & & \\
\hline \multicolumn{8}{|c|}{$\left[\mathrm{Et}_{2} \mathrm{NCMe}_{2} \mathrm{CH}=\mathrm{NPh}\right] \mathrm{PtCl}_{2}(\mathbf{5 c})$} \\
\hline Pt-N1 & $2.016(3)$ & $\mathrm{Pt}-\mathrm{N} 2$ & $2.119(3)$ & $\mathrm{Pt}-\mathrm{Cll}$ & $2.303(1)$ & $\mathrm{Pt}-\mathrm{Cl} 2$ & $2.311(1)$ \\
\hline $\mathrm{N} 1-\mathrm{C} 1$ & $1.281(5)$ & $\mathrm{N} 2-\mathrm{C} 2$ & $1.537(5)$ & $\mathrm{C} 1-\mathrm{C} 2$ & $1.504(5)$ & $\mathrm{N} 1-\mathrm{C} 21$ & $1.447(5)$ \\
\hline $\mathrm{N} 2-\mathrm{C} 5$ & $1.522(6)$ & $\mathrm{N} 2-\mathrm{C} 7$ & $1.524(6)$ & & & & \\
\hline $\mathrm{N} 1-\mathrm{Pt}-\mathrm{N} 2$ & $80.3(1)$ & $\mathrm{Cl} 1-\mathrm{Pt}-\mathrm{Cl} 2$ & $88.04(4)$ & $\mathrm{Pt}-\mathrm{N} 1-\mathrm{C} 1$ & $114.0(3)$ & & \\
\hline $\mathrm{Pt}-\mathrm{N} 2-\mathrm{C} 2$ & $104.1(2)$ & $\mathrm{N} 1-\mathrm{C} 1-\mathrm{C} 2$ & $120.1(3)$ & $\mathrm{N} 2-\mathrm{C} 2-\mathrm{C} 1$ & $105.7(3)$ & & \\
\hline $\mathrm{C} 5-\mathrm{N} 2-\mathrm{Pt}$ & $111.3(3)$ & $\mathrm{C} 7-\mathrm{N} 2-\mathrm{Pt}$ & $107.5(3)$ & $\mathrm{C} 21-\mathrm{N} 1-\mathrm{Pt}$ & $126.7(2)$ & & \\
\hline \multicolumn{8}{|c|}{$\left[\mathrm{Et}_{2} \mathrm{NCMe}_{2} \mathrm{CH}=\mathrm{NPh}\right] \mathrm{Pd}(\mathrm{OAc})_{2}(\mathbf{6 c})$} \\
\hline $\mathrm{Pd}-\mathrm{N} 1$ & $1.996(4)$ & $\mathrm{Pd}-\mathrm{N} 2$ & $2.075(4)$ & $\mathrm{Pd}-\mathrm{O} 1$ & $2.012(3)$ & $\mathrm{Pd}-\mathrm{O} 3$ & $2.012(3)$ \\
\hline $\mathrm{N} 1-\mathrm{C} 1$ & $1.271(6)$ & $\mathrm{N} 2-\mathrm{C} 2$ & $1.520(6)$ & $\mathrm{C} 1-\mathrm{C} 2$ & $1.502(6)$ & $\mathrm{N} 1-\mathrm{C} 21$ & $1.437(6)$ \\
\hline $\mathrm{N} 2-\mathrm{C} 5$ & $1.491(6)$ & $\mathrm{N} 2-\mathrm{C} 7$ & $1.524(5)$ & & & & \\
\hline $\mathrm{N} 1-\mathrm{Pd}-\mathrm{N} 2$ & $81.0(2)$ & $\mathrm{O} 1-\mathrm{Pd}-\mathrm{O} 3$ & $85.8(1)$ & $\mathrm{Pd}-\mathrm{N} 1-\mathrm{C} 1$ & $114.6(3)$ & & \\
\hline $\mathrm{Pd}-\mathrm{N} 2-\mathrm{C} 2$ & $104.3(3)$ & $\mathrm{N} 1-\mathrm{C} 1-\mathrm{C} 2$ & $118.2(5)$ & $\mathrm{N} 2-\mathrm{C} 2-\mathrm{C} 1$ & $105.7(4)$ & & \\
\hline $\mathrm{C} 5-\mathrm{N} 2-\mathrm{Pd}$ & $109.7(3)$ & C7-N2-Pd & $107.4(3)$ & $\mathrm{C} 21-\mathrm{N} 1-\mathrm{Pd}$ & $125.8(3)$ & & \\
\hline \multicolumn{8}{|c|}{$\left[\mathrm{Et}_{2} \mathrm{NCMe}_{2} \mathrm{CH}=\mathrm{N}^{\mathrm{i}} \mathrm{Pr}\right] \mathrm{Pd}(\mathrm{Me}) \mathrm{Cl}(\mathbf{7 a})$} \\
\hline $\mathrm{Pd}-\mathrm{N} 1$ & $2.046(3)$ & $\mathrm{Pd}-\mathrm{N} 2$ & $2.250(3)$ & $\mathrm{Pd}-\mathrm{C} 9$ & $2.022(4)$ & $\mathrm{Pd}-\mathrm{Cl1}$ & $2.306(1)$ \\
\hline $\mathrm{N} 1-\mathrm{C} 1$ & $1.282(6)$ & $\mathrm{N} 2-\mathrm{C} 2$ & $1.531(5)$ & $\mathrm{C} 1-\mathrm{C} 2$ & $1.478(8)$ & $\mathrm{N} 1-\mathrm{C} 21$ & $1.485(7)$ \\
\hline $\mathrm{N} 2-\mathrm{C} 5$ & $1.500(5)$ & $\mathrm{N} 2-\mathrm{C} 7$ & $1.485(5)$ & & & & \\
\hline N1-Pd-N2 & $78.3(1)$ & Cl1-Pd-C9 & $88.2(1)$ & $\mathrm{Pd}-\mathrm{N} 1-\mathrm{C} 1$ & $112.8(3)$ & & \\
\hline $\mathrm{Pd}-\mathrm{N} 2-\mathrm{C} 2$ & $100.5(2)$ & $\mathrm{N} 1-\mathrm{C} 1-\mathrm{C} 2$ & $122.7(3)$ & $\mathrm{N} 2-\mathrm{C} 2-\mathrm{C} 1$ & $106.1(3)$ & & \\
\hline $\mathrm{C} 5-\mathrm{N} 2-\mathrm{Pd}$ & $111.9(2)$ & $\mathrm{C} 7-\mathrm{N} 2-\mathrm{Pd}$ & $107.3(2)$ & $\mathrm{C} 21-\mathrm{N} 1-\mathrm{Pd}$ & $125.1(3)$ & & \\
\hline \multicolumn{8}{|c|}{$\left[\mathrm{Et}_{2} \mathrm{NCMe}_{2} \mathrm{CH}=\mathrm{NPh}\right] \mathrm{Pd}(\mathrm{Me}) \mathrm{Cl}(\mathbf{7 c})$} \\
\hline $\mathrm{Pd}-\mathrm{N} 1$ & $2.040(3)$ & $\mathrm{Pd}-\mathrm{N} 2$ & $2.270(3)$ & $\mathrm{Pd}-\mathrm{C} 9$ & $2.018(4)$ & $\mathrm{Pd}-\mathrm{Cl} 1$ & $2.310(2)$ \\
\hline $\mathrm{N} 1-\mathrm{C} 1$ & $1.268(5)$ & $\mathrm{N} 2-\mathrm{C} 2$ & $1.520(5)$ & $\mathrm{C} 1-\mathrm{C} 2$ & $1.498(8)$ & $\mathrm{N} 1-\mathrm{C} 21$ & $1.444(5)$ \\
\hline $\mathrm{N} 2-\mathrm{C} 5$ & $1.494(5)$ & $\mathrm{N} 2-\mathrm{C} 7$ & $1.485(5)$ & & & & \\
\hline $\mathrm{N} 1-\mathrm{Pd}-\mathrm{N} 2$ & $78.3(1)$ & $\mathrm{Cl1}-\mathrm{Pd}-\mathrm{C} 9$ & $87.5(1)$ & $\mathrm{Pd}-\mathrm{N} 1-\mathrm{C} 1$ & $115.1(3)$ & & \\
\hline $\mathrm{Pd}-\mathrm{N} 2-\mathrm{C} 2$ & $103.2(2)$ & $\mathrm{N} 1-\mathrm{C} 1-\mathrm{C} 2$ & $122.9(3)$ & $\mathrm{N} 2-\mathrm{C} 2-\mathrm{C} 1$ & $107.0(3)$ & & \\
\hline $\mathrm{C} 5-\mathrm{N} 2-\mathrm{Pd}$ & $110.7(2)$ & $\mathrm{C} 7-\mathrm{N} 2-\mathrm{Pd}$ & $106.4(2)$ & $\mathrm{C} 21-\mathrm{N} 1-\mathrm{Pd}$ & $126.9(2)$ & & \\
\hline \multicolumn{8}{|c|}{$\left[\mathrm{Et}_{2} \mathrm{NCMe}_{2} \mathrm{CH}=\mathrm{NPh}\right] \mathrm{Pd}(\mathrm{Me})(\mathrm{NCMe})$} $\mathrm{OTf}(\mathbf{8 c})$ \\
\hline $\mathrm{Pd}-\mathrm{N} 1$ & $2.027(3)$ & $\mathrm{Pd}-\mathrm{N} 2$ & $2.230(3)$ & $\mathrm{Pd}-\mathrm{C} 9$ & $2.007(4)$ & $\mathrm{Pd}-\mathrm{N} 3$ & $2.001(4)$ \\
\hline $\mathrm{N} 1-\mathrm{C} 1$ & $1.266(5)$ & $\mathrm{N} 2-\mathrm{C} 2$ & $1.509(5)$ & $\mathrm{C} 1-\mathrm{C} 2$ & $1.490(5)$ & N1-C21 & $1.437(5)$ \\
\hline $\mathrm{N} 2-\mathrm{C} 5$ & $1.501(5)$ & $\mathrm{N} 2-\mathrm{C} 7$ & $1.505(5)$ & N3-C10 & $1.123(5)$ & & \\
\hline $\mathrm{N} 1-\mathrm{Pd}-\mathrm{N} 2$ & $79.1(1)$ & N3-Pd-C9 & $86.9(2)$ & $\mathrm{Pd}-\mathrm{N} 1-\mathrm{C} 1$ & $113.3(3)$ & & \\
\hline $\mathrm{Pd}-\mathrm{N} 2-\mathrm{C} 2$ & $101.6(2)$ & N1-C1-C2 & $122.6(4)$ & $\mathrm{N} 2-\mathrm{C} 2-\mathrm{C} 1$ & 107.1(3) & & \\
\hline $\mathrm{C} 5-\mathrm{N} 2-\mathrm{Pd}$ & $109.9(2)$ & $\mathrm{C} 7-\mathrm{N} 2-\mathrm{Pd}$ & $108.1(2)$ & $\mathrm{C} 21-\mathrm{N} 1-\mathrm{Pd}$ & $127.0(2)$ & & \\
\hline C10-N3-Pd & 174.3(4) & & & & & & \\
\hline
\end{tabular}


Table 2 (Contd.)

\begin{tabular}{lccclcr}
$\left\{\left[\mathrm{Et}_{2} \mathrm{NCMe}{ }_{2} \mathrm{CH}=\mathrm{NPh}\right] \mathrm{Pd}\left[\mathrm{C}(\mathrm{O}) \mathrm{Me}\left(\mathrm{C}_{7} \mathrm{H}_{10}\right)\right]\right\} \mathrm{OTf}(\mathbf{1 0 c})$ & & & & \\
$\mathrm{Pd}-\mathrm{N} 1$ & $2.019(3)$ & $\mathrm{Pd}-\mathrm{N} 2$ & $2.227(3)$ & $\mathrm{Pd}-\mathrm{C} 9$ & $2.008(4)$ & $\mathrm{Pd}-\mathrm{O} 1$ \\
$\mathrm{~N} 1-\mathrm{C} 1$ & $1.280(5)$ & $\mathrm{N} 2-\mathrm{C} 2$ & $1.513(5)$ & $\mathrm{C} 1-\mathrm{C} 2$ & $1.501(6)$ & $\mathrm{N} 1-\mathrm{C} 21$ \\
$\mathrm{~N} 2-\mathrm{C} 5$ & $1.481(5)$ & $\mathrm{N} 2-\mathrm{C} 7$ & $1.488(5)$ & $\mathrm{O} 1-\mathrm{C} 16$ & $1.240(6)$ & $1.438(5)$ \\
$\mathrm{N} 1-\mathrm{Pd}-\mathrm{N} 2$ & $79.2(1)$ & $\mathrm{O} 1-\mathrm{Pd}-\mathrm{C} 9$ & $83.6(2)$ & $\mathrm{Pd}-\mathrm{N} 1-\mathrm{C} 1$ & $113.7(3)$ & \\
$\mathrm{Pd}-\mathrm{N} 2-\mathrm{C} 2$ & $101.5(2)$ & $\mathrm{N} 1-\mathrm{C} 1-\mathrm{C} 2$ & $121.4(4)$ & $\mathrm{N} 2-\mathrm{C} 2-\mathrm{C} 1$ & $106.2(3)$ & \\
$\mathrm{C} 5-\mathrm{N} 2-\mathrm{Pd}$ & $107.9(3)$ & $\mathrm{C} 7-\mathrm{N} 2-\mathrm{Pd}$ & $109.4(2)$ & $\mathrm{C} 21-\mathrm{N} 1-\mathrm{Pd}$ & $126.7(3)$ & \\
$\mathrm{C} 14-\mathrm{C} 9-\mathrm{Pd}$ & $109.0(3)$ & $\mathrm{C} 16-\mathrm{O} 1-\mathrm{Pd}$ & $115.2(3)$ & & & \\
\hline
\end{tabular}
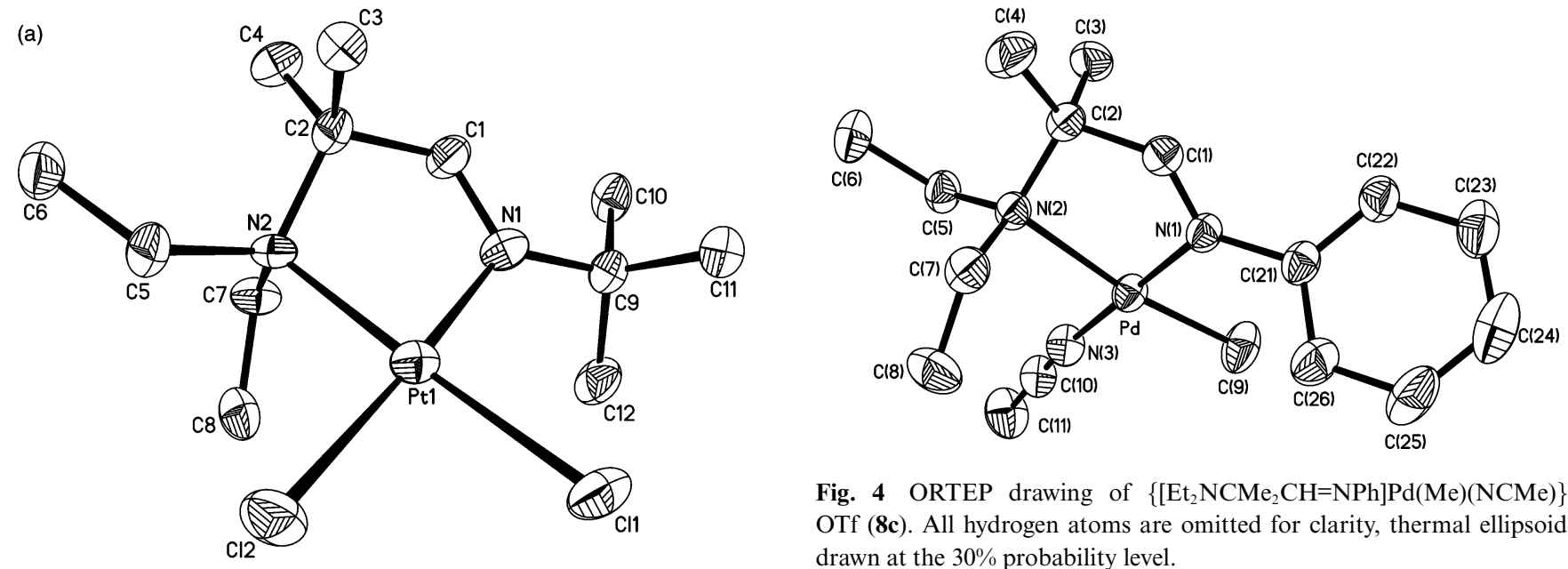

Fig. 4 ORTEP drawing of $\left\{\left[\mathrm{Et}_{2} \mathrm{NCMe}_{2} \mathrm{CH}=\mathrm{NPh}\right] \mathrm{Pd}(\mathrm{Me})(\mathrm{NCMe})\right\}-$ OTf $(\mathbf{8 c})$. All hydrogen atoms are omitted for clarity, thermal ellipsoids drawn at the $30 \%$ probability level.

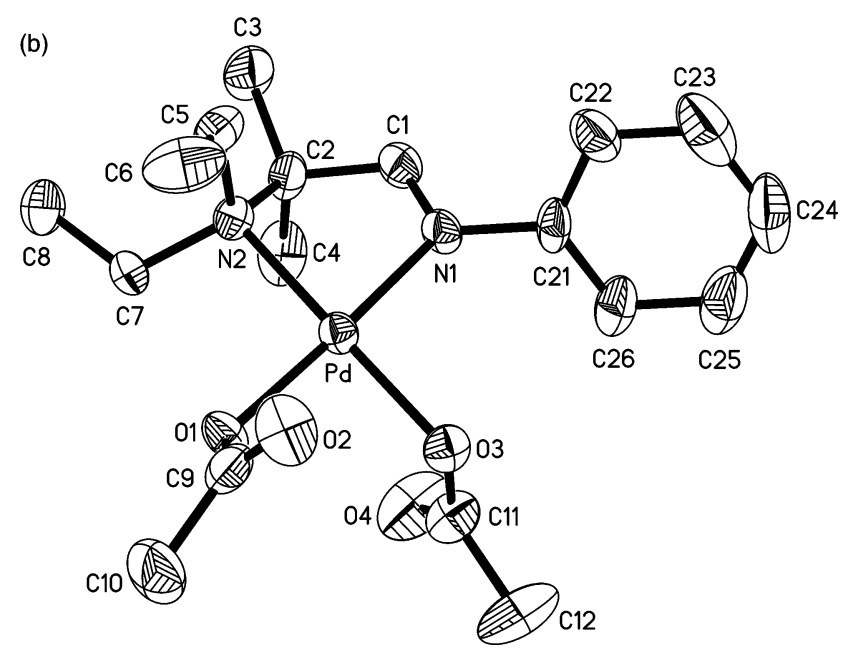

Fig. 3 ORTEP drawings of (a) $\left[\mathrm{Et}_{2} \mathrm{NCMe}_{2} \mathrm{CH}=\mathrm{N}^{t} \mathrm{Bu}\right] \mathrm{PtCl}_{2}$ (5b), and (b) $\left[\mathrm{Et}_{2} \mathrm{NCMe}_{2} \mathrm{CH}=\mathrm{NPh}\right] \mathrm{Pd}(\mathrm{OAc})_{2}(\mathbf{6 c})$. All hydrogen atoms are omitted for clarity.

is attributed to the large trans influence of the Pd-bound methyl. Despite the slight lengthening of the $\mathrm{Pd}-\mathrm{N} 1$ and $\mathrm{Pd}-\mathrm{N} 2$ bonds in the organometallic complexes, the bite-angles of N1-Pd-N2 in 7a and $7 \mathbf{c}$ are smaller $\left(1-2^{\circ}\right)$ than in the corresponding dichloro complexes $\mathbf{4 a}$ and $\mathbf{4 c}$, respectively; however, they are slightly larger than in the methylchloro analogues of the diimino complexes. ${ }^{19}$

\section{Geometrical isomerism}

All the prepared organometallic derivatives with the title ligands show a single geometrical isomer of the trans configuration,

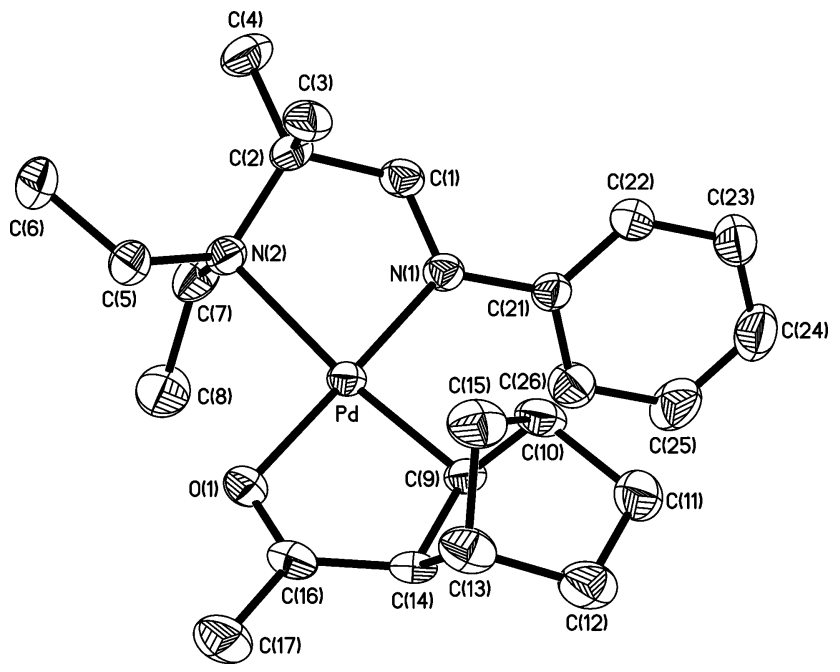

Fig. 5 ORTEP drawing of $\left\{\left[\mathrm{Et}_{2} \mathrm{NCMe}_{2} \mathrm{CH}=\mathrm{NPh}\right] \mathrm{Pd}\left[\mathrm{C}(\mathrm{O}) \mathrm{Me}\left(\mathrm{C}_{7} \mathrm{H}_{10}\right)\right]\right\}-$ OTf (10c). All hydrogen atoms are omitted for clarity, thermal ellipsoids drawn at the $30 \%$ probability level.

even the products from the reaction of $\mathrm{CO}$ or olefin insertion as illustrated in Scheme 4. The stereo-retention of $\mathrm{CO}$ insertion and norbornene insertion may be explained either by a pathway involving a five-coordinate intermediacy, ${ }^{20}$ or isomerization via amine dissociation and re-coordination. ${ }^{21}$

In complexes $\mathbf{7 a}$ and $\mathbf{7 c}$, the trans isomerism appears to be not affected by the isopropyl or phenyl group on the imine. Such a stereoselectivity is attributed to steric hindrance between the methyl ligand in $\mathbf{7}$ or $\mathbf{8}$, acetyl in $\mathbf{9}$ or norbornyl in $\mathbf{1 0}$ and the ethyl substituents of amine functionality that could destabilize the 
Table 3 Selected bond parameters from crystallographic analysis

\begin{tabular}{lllll}
\hline Complex & $\mathrm{Pd}-\mathrm{N} 1(\AA)$ & $\mathrm{Pd}-\mathrm{N} 2(\AA)$ & $\mathrm{N} 1-\mathrm{Pd}-\mathrm{N} 2\left(^{\circ}\right)$ & $\mathrm{L} 1-\mathrm{Pd}-\mathrm{L} 2^{a}\left({ }^{\circ}\right)$ \\
\hline $\mathbf{4 a}$ & $2.028(3)$ & $2.126(4)$ & $79.8(1)$ & $89.31(6)$ \\
$\mathbf{4 c}$ & $2.026(2)$ & $2.115(2)$ & $80.03(8)$ & $88.61(3)$ \\
trans-7a & $2.046(3)$ & $2.250(3)$ & $78.3(1)$ & $88.2(1)$ \\
trans-7c & $2.040(3)$ & $2.270(3)$ & $78.3(1)$ & $87.5(1)$ \\
trans-8c & $2.027(3)$ & $2.230(3)$ & $79.1(1)$ & $86.9(2)$ \\
trans-exo-10c & $2.019(3)$ & $2.227(3)$ & $79.2(1)$ & $83.6(2)$
\end{tabular}

${ }^{a} \mathrm{~L} 1$ : the donor atom trans to imine; L2: the donor atom trans to amine.

cis form. ${ }^{22}$ The two methyl substituents on the $\alpha$-carbon (C2) of aminoaldimines might enhance this hindrance. On the other hand, the imino functionality in which the trigonal planar disposition around the $\mathrm{N}\left(\mathrm{sp}^{2}\right)$ is supposed to be more tolerable to the steric strain than the $\mathrm{N}\left(\mathrm{sp}^{3}\right)$. Besides, teriary amines are known to be hemi-labile. ${ }^{23}$ It is reasonable to assume that the trans isomerism is a thermodynamic result of isomerization via amine dissociation and re-coordination.

\section{Calculational analysis}

In order to seek theoretical support for the stereoselectivity to the trans geometrical isomers, DFT calculations of the energy differences between the trans and cis isomers of $7 \mathbf{a}, 7 \mathbf{c}, 8 \mathbf{c}, 9 \mathbf{c}$ and the trans/cis-exo/endo forms for 10c have been carried out.

The results regarding the calculated relative stability between the isomers are consistent with the experimental observations. As the data listed in Table 4 shows, the neutral complexes of trans-7a, trans-7c, and trans-9c are more stable than their corresponding cis isomers by $4.08,5.21$, and $4.78 \mathrm{kcal} \mathrm{mol}^{-1}$, respectively. For the cationic complex $\mathbf{8 c}$, the trans form is more favorable by only 2.62

Table 4 DFT calculations for the relative stability of organopalladium stereoisomers

\begin{tabular}{lll}
\hline Complex & trans $\left(\mathrm{kcal} \mathrm{mol}^{-1}\right)$ & cis $\left(\mathrm{kcal} \mathrm{mol}^{-1}\right)$ \\
\hline $\mathbf{7 a}$ & 0 & 4.08 \\
$\mathbf{7 c}$ & 0 & 5.21 \\
$\mathbf{8 c}$ & 0 & 2.62 \\
$\mathbf{9 c}$ & 0 & 4.78 \\
$\mathbf{1 0 c}-$ exo & 0 & 5.51 \\
10c-endo & $1.47^{a}$ & - \\
\multicolumn{2}{l}{ Relative to 10c-trans-exo. } & \\
\hline
\end{tabular}

$\mathrm{kcal} \mathrm{mol}^{-1}$. For 10c, the trans-syn/exo, trans-syn/endo, and the cis-syn/exo configurations have been compared. The cis-exo form is $5.51 \mathrm{kcal} \mathrm{mol}^{-1}$, while the trans-endo form is $1.47 \mathrm{kcal} \mathrm{mol}^{-1}$ less stable than the trans-exo form that is the sole isomer observed by $\mathrm{X}$-ray diffractions.

The structural parameters from the theoretical approach are listed in Table 5. It is shown that all of the biting angles of $\mathrm{N} 1-\mathrm{Pd}-\mathrm{N} 2$ are about $3^{\circ}$ smaller than the data from X-Ray analysis. But the angles of L1-Pd-L2 are matched well. Comparing the theoretical structures for the geometrical isomers of 7a, 7c, 8c and 9c, the larger bond lengths between $\mathrm{Pd}-\mathrm{N} 1$ and $\mathrm{Pd}-\mathrm{N} 2$ in the trans species rather than in cis could be attributed to the trans influence. However, it is difficult to ascribe the favorable stability of the trans form to electronic or steric effect according to these data.

In the case of 10c, the bond parameters of trans-exo derivative between the calculated and the experimental data are rather comparable. In the trans-endo form, the hindrance appears to be mainly resulting from a methyl on the $\alpha$-carbon of the bidentate ligand and the $\mathrm{H}$ of nobornyl bridge. The closest $\mathrm{H} \cdots \mathrm{H}$ distance is $2.313 \AA$ (whilst $3.025 \AA$ in trans-exo), as shown in Fig. 6(a) and $6(\mathrm{~b})$. In the cis-exo form, multiple $\mathrm{H} \cdots \mathrm{H}$ hindrances likely result from the interaction between the amino ethyl groups and the norbornyl group. In Fig. 6(c), three sets of $\mathrm{H} \cdots \mathrm{H}$ distance within $2.3 \AA$ are found. It indicates that the respective steric effects from

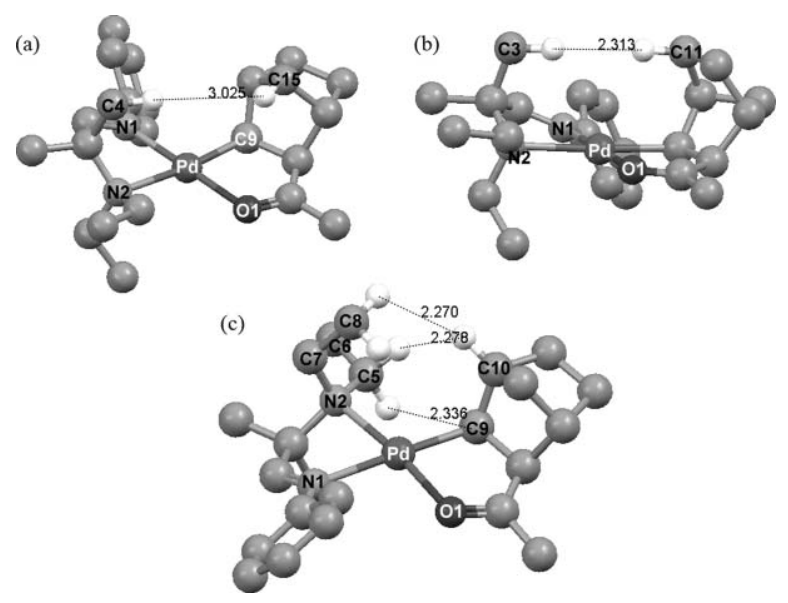

Fig. 6 Calculated steric hindrance in 10c of (a) trans-exo, (b) trans-endo, (c) cis-exo.

Table 5 Selected bond parameters from calculations

\begin{tabular}{|c|c|c|c|c|c|c|c|}
\hline$c i s-7 \mathbf{a}$ & 2.201 & 2.337 & 1.259 & $2.072(L 1=C 9)$ & $2.369(L 2=C l 1)$ & 74.99 & 88.07 \\
\hline trans $-\mathbf{7 a}$ & 2.138 & 2.416 & 1.268 & $2.071(L 1=C 9)$ & $2.366(L 2=C l 1)$ & 74.99 & 88.16 \\
\hline trans $-7 \mathbf{c}$ & 2.131 & 2.421 & 1.275 & $2.073(L 1=C 9)$ & $2.369(L 2=C l 1)$ & 75.15 & 88.22 \\
\hline$c i s-\mathbf{8 c}$ & 2.223 & 2.260 & 1.265 & $2.080(L 1=C 9)$ & $2.064(L 2=N 3)$ & 76.15 & 87.27 \\
\hline trans-8c & 2.105 & 2.371 & 1.273 & $2.083(L 1=C 9)$ & $2.065(L 2=N 3)$ & 76.23 & 86.76 \\
\hline trans-endo-10c & 2.224 & 2.279 & 1.275 & $2.089(L 1=C 9)$ & $2.133(L 2=O 1)$ & 74.73 & 80.81 \\
\hline trans-exo-10c & 2.113 & 2.334 & 1.274 & $2.073(L 1=C 9)$ & $2.123(L 2=O 1)$ & 76.74 & 81.52 \\
\hline
\end{tabular}

${ }^{a} \mathrm{~L} 1$ : the donor atom trans to imine. ${ }^{b} \mathrm{~L} 2$ : the donor atom trans to amine. 
the amino and imino functionalities of such aldimines are crucial to the geometrical isomerism in the square planar configuration.

\section{Concluding remarks}

New unsymmetric bidentate ligands of $\alpha$-aminoaldimines in the formula of $\mathrm{Et}_{2} \mathrm{NCMe}_{2} \mathrm{CH}=\mathrm{NR}$ are synthesized. A tetrahedral dichloronickel(II) complex and square planar dichloro and diacetato complexes of palladium or platinum are synthesized. The amine and imine functionalities show comparable trans influence. Square planar organometallic complexes of palladium with selective geometrical isomerism favored by the trans configuration are acquired. Such a stereoselectivity is a result of the thermodynamic option governed predominantly by the steric control from the hetero-donating functionalities of the ligand. In more specific words, the bulkier ligands prefer to coordinate cis to the imine group rather than amine group in the studied cases, so that the steric hindrance could be minimized.

\section{Experimental section}

\section{Synthesis and spectral characterization}

General procedures. Commercially available reagents were purchased and used without further purification unless otherwise indicated. Organic solvents were dried from purple solutions of benzophenone ketyl or over $\mathrm{P}_{2} \mathrm{O}_{5}$ under nitrogen, and distilled immediately prior to use. Air-sensitive material was manipulated under a nitrogen atmosphere in a glove box or by standard Schlenk techniques. The IR spectra were recorded on a Bio-Rad FTS-40 spectrophotometer. The NMR spectra were measured on Bruker AC-200, AC-300, or AC-400 spectrometer. The corresponding frequencies for ${ }^{13} \mathrm{C}$ NMR spectra were 50.324 and $75.469 \mathrm{MHz}$, or $100.625 \mathrm{MHz}$ respectively. Values upfield of ${ }^{1} \mathrm{H}$ and ${ }^{13} \mathrm{C}$ data are given in $\delta$ relative to tetramethylsilane $(\delta 0.00)$ in $\mathrm{CDCl}_{3}$ or to benzene in $d^{6}$-benzene $\left(7.15, \mathrm{C}_{6} \mathrm{H}_{6} ; 128.7, \mathrm{C}_{6} \mathrm{H}_{6}\right)$. Mass spectrometric analyses were collected on a Finnigan TSQ-46C or JEOL SX-102A spectrometer. Elemental analysis was done on a Perkin-Elmer $2400 \mathrm{CHN}$ analyzer.

$\mathrm{BrCMe}_{2} \mathrm{CHO}$ (1). Orange bromine-1,4-dioxane adduct (32.7 $\mathrm{g}, 0.132 \mathrm{~mol})$ was added in several aliquots to 2methylpropanal $(10 \mathrm{~g}, 0.139 \mathrm{~mol})$ in $50 \mathrm{~mL}$ of diethyl ether at $5{ }^{\circ} \mathrm{C}$. The orange slurry was continuously stirred until the disappearance of the color. The resulting solution was stirred for 10 min more, and then extracted three times with ice-cold water. The solution was dried with $\mathrm{MgSO}_{4}$ and ether was removed on a rotary evaporator. The yield was $70 \%$. IR $(\mathrm{KBr}): v_{\mathrm{CO}} 1733 \mathrm{~cm}^{-1}$; ${ }^{1} \mathrm{H} \mathrm{NMR}\left(\mathrm{CDCl}_{3}\right): \delta 9.34(\mathrm{~s}, 1 \mathrm{H}, \mathrm{CHO}), 1.77\left(\mathrm{~s}, 6 \mathrm{H}, \mathrm{CH}_{3}\right) ;{ }^{13} \mathrm{C}$ $\mathrm{NMR}\left(\mathrm{CDCl}_{3}\right): \delta 192.8(\mathrm{CHO}), 63.8\left(\mathrm{CMe}_{2} \mathrm{Br}\right), 26.5\left(\mathrm{CH}_{3}\right)$; $\mathrm{MS}$ $(\mathrm{FAB}, m / z): 151\left(\mathrm{M}^{+}\right)$.

$\mathbf{E t}_{2} \mathrm{NCMe}_{2} \mathbf{C H O}$. In a round-bottom flask was placed $\mathrm{BrCMe}_{2} \mathrm{CHO}(14 \mathrm{~g}, 92 \mathrm{mmol})$ in $30 \mathrm{~mL}$ of diethyl ether. The solution was first cooled to $0{ }^{\circ} \mathrm{C}$. $\mathrm{Et}_{2} \mathrm{NH}(17 \mathrm{~g}, 233 \mathrm{mmol})$ was added dropwise. The mixture was then stirred for $4 \mathrm{~h}$ to allow the reaction to complete. After the removal of amine salt, the solution was distilled to give a viscous yellow liquid product in $88 \%$ yield (11.7 g). IR (KBr): $v_{\mathrm{CO}} 1739 \mathrm{~cm}^{-1} ;{ }^{1} \mathrm{H} \mathrm{NMR}\left(\mathrm{CDCl}_{3}\right): \delta 9.39$ (s, $1 \mathrm{H}, \mathrm{CHO}$ ), 2.50 (q, $\left.J_{\mathrm{H}-\mathrm{H}}=7.1 \mathrm{~Hz}, 4 \mathrm{H}, \mathrm{NCH}_{2} \mathrm{CH}_{3}\right), 1.07$ (s, 6H,
$\left.\mathrm{C}\left(\mathrm{CH}_{3}\right)_{2}\right), 1.02\left(\mathrm{t}, \mathrm{J}_{\mathrm{H}-\mathrm{H}}=7.1 \mathrm{~Hz}, 6 \mathrm{H}, \mathrm{NCH}_{2} \mathrm{CH}_{3}\right) ;{ }^{13} \mathrm{C} \mathrm{NMR}$ $\left(\mathrm{CDCl}_{3}\right): \delta 205.5(\mathrm{CHO}), 66.7\left(C\left(\mathrm{CH}_{3}\right)_{2}\right), 43.4\left(\mathrm{NCH}_{2} \mathrm{CH}_{3}\right), 18.9$ $\left(\mathrm{C}\left(\mathrm{CH}_{3}\right)_{2}\right), 16.0\left(\mathrm{NCH}_{2} \mathrm{CH}_{3}\right) ; \mathrm{MS}(\mathrm{FAB}, \mathrm{m} / z): 143\left(\mathrm{M}^{+}\right)$.

$\mathbf{E t}_{2} \mathbf{N C M e}_{2} \mathbf{C H}=\mathbf{N}^{\mathrm{i}} \mathbf{P r}$ (2a). In a round-bottom flask was placed $\mathrm{Et}_{2} \mathrm{NCMe}_{2} \mathrm{CHO}$ (4.33 g, $\left.30.3 \mathrm{mmol}\right)$ and isopropylamine $(1.9 \mathrm{~g}$, $32.8 \mathrm{mmol}$ ) in $100 \mathrm{~mL}$ of benzene. The solution was stirred with $4 \AA$ molecular sieves at $25^{\circ} \mathrm{C}$. Distillation under vacuum gave colorless liquid product in $49 \%$ yield $(2.7 \mathrm{~g})$. IR $(\mathrm{KBr}): v_{\mathrm{CN}} 1666 \mathrm{~cm}^{-1} ;{ }^{1} \mathrm{H}$ $\operatorname{NMR}\left(\mathrm{CDCl}_{3}\right) \delta 7.51(\mathrm{~s}, 1 \mathrm{H}, \mathrm{CH}=\mathrm{N}), 3.27\left(\mathrm{~h}, J_{\mathrm{H}-\mathrm{H}}=6.8 \mathrm{~Hz}\right.$, $\left.1 \mathrm{H}, \mathrm{NCH}\left(\mathrm{CH}_{3}\right)_{2}\right), 2.50\left(\mathrm{q}, J_{\mathrm{H}-\mathrm{H}}=7.2 \mathrm{~Hz}, 4 \mathrm{H}, \mathrm{NCH}_{2} \mathrm{CH}_{3}\right), 1.12$ $\left(\mathrm{s}, 6 \mathrm{H}, \mathrm{C}\left(\mathrm{CH}_{3}\right)_{2}\right), 1.10\left(\mathrm{~d}, J_{\mathrm{H}-\mathrm{H}}=6.8 \mathrm{~Hz}, 6 \mathrm{H}, \mathrm{NCH}\left(\mathrm{CH}_{3}\right)_{2}\right), 1.00$ $\left(\mathrm{t}, J_{\mathrm{H}-\mathrm{H}}=7.2 \mathrm{~Hz}, 6 \mathrm{H}, \mathrm{NCH}_{2} \mathrm{CH}_{3}\right) ;{ }^{13} \mathrm{C} \mathrm{NMR}\left(\mathrm{CDCl}_{3}\right): \delta 168.3$ $(C=\mathrm{N}), 61.1\left(C\left(\mathrm{CH}_{3}\right)_{2}\right), 61.0\left(\mathrm{NCH}\left(\mathrm{CH}_{3}\right)_{2}\right), 43.2\left(\mathrm{NCH}_{2} \mathrm{CH}_{3}\right)$, $23.9\left(\mathrm{C}\left(\mathrm{CH}_{3}\right)_{2}\right), 22.0\left(\mathrm{NCH}\left(\mathrm{CH}_{3}\right)_{2}\right), 16.4\left(\mathrm{NCH}_{2} \mathrm{CH}_{3}\right)$; $\mathrm{MS}$ (FAB, $m / z): 185.2\left(\mathrm{M}^{+}+1\right)$.

$\mathbf{E t}_{2} \mathrm{NCMe}_{2} \mathbf{C H}=\mathbf{N}^{t} \mathbf{B u}$ (2b). Using ${ }^{t} \mathrm{BuNH}_{2}$ and following the similar procedure as the preparation for $\mathbf{2 a}$ gave the product of 2b in a yield of $76 \% .{ }^{1} \mathrm{H}$ NMR $\left(\mathrm{CDCl}_{3}\right): \delta 7.48(\mathrm{~s}, 1 \mathrm{H}, \mathrm{CH}=\mathrm{N})$, $2.51\left(\mathrm{q}, J_{\mathrm{H}-\mathrm{H}}=7.1 \mathrm{~Hz}, 4 \mathrm{H}, \mathrm{NCH}_{2} \mathrm{CH}_{3}\right), 1.13\left(\mathrm{~s}, 9 \mathrm{H}, \mathrm{C}\left(\mathrm{CH}_{3}\right)_{3}\right)$, $1.12\left(\mathrm{~s}, 6 \mathrm{H}, \mathrm{C}\left(\mathrm{CH}_{3}\right)_{2}\right), 1.02\left(\mathrm{t}, J_{\mathrm{H}-\mathrm{H}}=7.1 \mathrm{~Hz}, 6 \mathrm{H}, \mathrm{NCH}_{2} \mathrm{CH}_{3}\right)$; ${ }^{13} \mathrm{C} \mathrm{NMR}\left(\mathrm{CDCl}_{3}\right): \delta 165.0(\mathrm{CH}=\mathrm{N}), 61.44\left(\mathrm{C}\left(\mathrm{CH}_{3}\right)_{3}\right), 56.16$ $\left(\mathrm{C}\left(\mathrm{CH}_{3}\right)_{2}\right), 43.30\left(\mathrm{NCH}_{2} \mathrm{CH}_{3}\right), 29.63\left(\mathrm{C}\left(\mathrm{CH}_{3}\right)_{3}\right), 21.73\left(\mathrm{C}\left(\mathrm{CH}_{3}\right)_{2}\right)$, $16.40\left(\mathrm{NCH}_{2} \mathrm{CH}_{3}\right)$.

$\mathbf{E t}_{2} \mathrm{NCMe}_{2} \mathbf{C H}=\mathbf{N P h}(2 \mathrm{c})$. In a round-bottom flask was added $\mathrm{Et}_{2} \mathrm{NCMe}_{2} \mathrm{CHO}(7.0 \mathrm{~g}, 49 \mathrm{mmol})$ and then aniline $(7.6 \mathrm{~g}, 82 \mathrm{mmol})$ in $150 \mathrm{~mL}$ of benzene. The solution was refluxed under nitrogen with Dean-Stark set-up. The product was isolated as a viscous colorless liquid by distillation under vacuum. The yield was $66 \%$ $(11.8 \mathrm{~g})$. IR (KBr): $v_{\mathrm{CN}} 1648 \mathrm{~cm}^{-1} ;{ }^{1} \mathrm{H}$ NMR $\left(\mathrm{CDCl}_{3}\right): \delta 7.75(\mathrm{~s}$, $1 \mathrm{H}, \mathrm{CH}=\mathrm{N}), 7.35-6.99(\mathrm{~m}, 5 \mathrm{H}$, phenyl- $H), 2.61\left(\mathrm{q}, J_{\mathrm{H}-\mathrm{H}}=7.0 \mathrm{~Hz}\right.$, $\left.4 \mathrm{H}, \mathrm{NCH}_{2} \mathrm{CH}_{3}\right), 1.28\left(\mathrm{~s}, 6 \mathrm{H}, \mathrm{C}\left(\mathrm{CH}_{3}\right)_{2}\right), 1.06\left(\mathrm{t}, J_{\mathrm{H}-\mathrm{H}}=7.0 \mathrm{~Hz}, 6 \mathrm{H}\right.$, $\left.\mathrm{NCH}_{2} \mathrm{CH}_{3}\right) ;{ }^{13} \mathrm{C} \mathrm{NMR}\left(\mathrm{CDCl}_{3}\right): \delta 172.6(\mathrm{C}=\mathrm{N}), 151.8,130-112$ (phenyl- $\mathrm{C}$ ), $63.0\left(\mathrm{C}\left(\mathrm{CH}_{3}\right)_{2}\right), 43.8\left(\mathrm{NCH}_{2} \mathrm{CH}_{3}\right), 21.8\left(\mathrm{C}\left(\mathrm{CH}_{3}\right)_{2}\right)$, $15.8\left(\mathrm{NCH}_{2} \mathrm{CH}_{3}\right)$; $\mathrm{MS}(\mathrm{FAB}, \mathrm{m} / z): 219.2\left(\mathrm{M}^{+}+1\right)$. Anal. calcd for $\mathrm{C}_{14} \mathrm{H}_{22} \mathrm{~N}_{2}$ : C, 77.01; H, 10.16; N, 12.83\%. Found: C, 76.43; H, $10.01 ; \mathrm{N}, 12.32 \%$.

$\left[\mathbf{E t}_{2} \mathbf{N C M e}_{2} \mathbf{C H}=\mathbf{N P h}\right] \mathbf{N i C l}_{2} \quad(\mathbf{3 c}) . \quad(\mathrm{DME}) \mathrm{NiCl}_{2} \quad(300 \mathrm{mg}, 1$ $\mathrm{mmol}$ ) and $2 \mathrm{c}(327 \mathrm{mg}, 1.5 \mathrm{mmol}$ ) were placed in a round-bottom flask under nitrogen. Predried $\mathrm{CH}_{2} \mathrm{Cl}_{2}(15 \mathrm{~mL})$ was transferred under vacuum. The orange solution turned to violet within $10 \mathrm{~min}$. The reaction was allowed to complete at $25{ }^{\circ} \mathrm{C}$. After removal of the supernatant solid, the reaction solution was concentrated. Addition of dry $\mathrm{Et}_{2} \mathrm{O}$ resulted in the solid product, and the yield of $1 \mathbf{a}$ was $62 \%(270 \mathrm{mg})$ after recrystallization from $\mathrm{CH}_{2} \mathrm{Cl}_{2}-\mathrm{Et}_{2} \mathrm{O}$.

$\left[\mathbf{E t}_{\mathbf{2}} \mathbf{N C M e}_{\mathbf{2}} \mathbf{C H}=\mathbf{N} \mathbf{P r}\right] \mathbf{P d C l} \mathbf{}_{\mathbf{2}}$ (4a). To a $20 \mathrm{~mL} \mathrm{CH}_{2} \mathrm{Cl}_{2}$ solution containing $(\mathrm{PhCN})_{2} \mathrm{PdCl}_{2}(547 \mathrm{mg}, 1.428 \mathrm{mmol})$ was added the ligand 2a $(270 \mathrm{mg}, 1.467 \mathrm{mmol})$. The solution was stirred at $25^{\circ} \mathrm{C}$ for $45 \mathrm{~min}$, then was concentrated. Addition of diethyl ether gave the yellow precipitate in $93 \%$ yield $(480 \mathrm{mg}$ ). Single crystals suitable for $\mathrm{X}$-ray analysis were obtained by recrystallization from $\mathrm{CH}_{2} \mathrm{Cl}_{2}-\mathrm{Et}_{2} \mathrm{O}$. IR (KBr pellet): $v_{\mathrm{CN}} 1655 \mathrm{~cm}^{-1} ;{ }^{1} \mathrm{H} \mathrm{NMR}\left(\mathrm{CD}_{3} \mathrm{CN}\right)$ : $\delta 7.36(\mathrm{~s}, 1 \mathrm{H}, \mathrm{CH}=\mathrm{N}), 4.54\left(\mathrm{~h}, J_{\mathrm{H}-\mathrm{H}}=6.6 \mathrm{~Hz}, 1 \mathrm{H}, \mathrm{NCH}\left(\mathrm{CH}_{3}\right)_{2}\right)$, $3.13,2.99\left(\mathrm{~m}, J_{\mathrm{H}-\mathrm{H}}=7.2,14.6 \mathrm{~Hz}, 4 \mathrm{H}, \mathrm{NCH}_{2} \mathrm{CH}_{3}\right), 1.82(\mathrm{~s}$, $\left.6 \mathrm{H}, \mathrm{C}\left(\mathrm{CH}_{3}\right)_{2}\right), 1.49\left(\mathrm{t}, J_{\mathrm{H}-\mathrm{H}}=7.2 \mathrm{~Hz}, 6 \mathrm{H}, \mathrm{NCH}_{2} \mathrm{CH}_{3}\right), 1.31$ (d, $\left.J_{\mathrm{H}-\mathrm{H}}=6.6 \mathrm{~Hz}, 6 \mathrm{H}, \mathrm{NCH}\left(\mathrm{CH}_{3}\right)_{2}\right),{ }^{13} \mathrm{C} \mathrm{NMR}\left(\mathrm{CD}_{3} \mathrm{CN}\right): \delta 176.8$ $(C=\mathrm{N}), 75.0\left(C\left(\mathrm{CH}_{3}\right)_{2}\right), 56.7\left(\mathrm{NCH}\left(\mathrm{CH}_{3}\right)_{2}\right), 49.2\left(\mathrm{NCH}_{2} \mathrm{CH}_{3}\right)$, 
$23.3\left(\mathrm{C}\left(\mathrm{CH}_{3}\right)_{2}\right), 21.9\left(\mathrm{NCH}\left(\mathrm{CH}_{3}\right)_{2}\right), 13.1\left(\mathrm{NCH}_{2} \mathrm{CH}_{3}\right)$; $\mathrm{MS}$ (FAB, $m / z)$ : $327.0\left(\mathrm{M}^{+}+1-\mathrm{Cl}\right)$. Anal. calcd for $\mathrm{C}_{11} \mathrm{H}_{24} \mathrm{Cl}_{2} \mathrm{~N}_{2} \mathrm{Pd}$ : $\mathrm{C}$, 36.53 ; H, 6.69; N, 7.75\%. Found: C, 35.74; H, 6.57; N, 7.62\%.

$\left[\mathbf{E t}_{2} \mathbf{N C M e}_{2} \mathbf{C H}=\mathbf{N P h}\right] \mathbf{P d C l}_{\mathbf{2}}(\mathbf{4 c})$. Using similar procedures as for $4 \mathbf{a}$, the reaction of $(\mathrm{PhCN})_{2} \mathrm{PdCl}_{2}(395 \mathrm{mg}, 0.969 \mathrm{mmol})$ and ligand $2 \mathrm{c}(235 \mathrm{mg}, 1.078 \mathrm{mmol})$ gave the yellow precipitate of $\mathbf{4 c}$ in $95 \%$ yield (389 mg). Single crystals were grown from $\mathrm{CH}_{2} \mathrm{Cl}_{2}-\mathrm{Et}_{2} \mathrm{O}$ cosolvents. IR (KBr): $v_{\mathrm{CN}} 1627 \mathrm{~cm}^{-1} ;{ }^{1} \mathrm{H} \mathrm{NMR}\left(\mathrm{CDCl}_{3}\right): \delta 7.57(\mathrm{~s}$, $1 \mathrm{H}, \mathrm{C} H=\mathrm{N}), 7.48-7.20(\mathrm{~m}, 5 \mathrm{H}$, phenyl- $H), 3.22,3.07\left(\mathrm{br}, J_{\mathrm{H}-\mathrm{H}}=\right.$ $\left.7.1 \mathrm{~Hz}, 2 \mathrm{H}, 2 \mathrm{H}, \mathrm{NCH}_{2} \mathrm{CH}_{3}\right), 1.88\left(\mathrm{~s}, 6 \mathrm{H}, \mathrm{C}\left(\mathrm{CH}_{3}\right)_{2}\right), 1.54\left(\mathrm{t}, J_{\mathrm{H}-\mathrm{H}}=\right.$ $\left.7.1 \mathrm{~Hz}, 6 \mathrm{H}, \mathrm{NCH}_{2} \mathrm{CH}_{3}\right) ;{ }^{13} \mathrm{C} \mathrm{NMR}\left(\mathrm{CDCl}_{3}\right): \delta 183.1(\mathrm{C}=\mathrm{N}), 128.7$, 128.6, 123.2 (phenyl- $C$ ), $74.7\left(\mathrm{C}\left(\mathrm{CH}_{3}\right)_{2}\right), 49.5\left(\mathrm{NCH}_{2} \mathrm{CH}_{3}\right), 23.1$ $\left(\mathrm{C}\left(\mathrm{CH}_{3}\right)_{2}\right), 13.3\left(\mathrm{NCH}_{2} \mathrm{CH}_{3}\right)$; $\mathrm{MS}(\mathrm{FAB}, \mathrm{m} / z)$ : $323.1\left(\mathrm{M}^{+}-2 \mathrm{Cl}\right)$, $359\left(\mathrm{M}^{+}-\mathrm{Cl}\right)$. Anal. calcd for $\mathrm{C}_{14} \mathrm{H}_{22} \mathrm{Cl}_{2} \mathrm{~N}_{2} \mathrm{Pd}$ : C, 42.50; H, 5.60; N, 7.08\%. Found: C, 41.66; H, 5.09; N, 6.91\%.

$\left[\mathbf{E t}_{2} \mathbf{N C M e}_{2} \mathbf{C H}=\mathbf{N}^{t} \mathbf{B u}_{\mathbf{P t C l}} \mathbf{2}\right.$ (5b). A similar procedure as the preparation for $\mathbf{5} \mathbf{c}$ gave the product in a yield of $42 \%$. Single crystals suitable for $\mathrm{X}$-ray analysis were obtained by recrystallization from $\mathrm{CH}_{2} \mathrm{Cl}_{2}-\mathrm{Et}_{2} \mathrm{O}$. IR ( $\left.\mathrm{KBr}\right): v_{\mathrm{CN}} 1633 \mathrm{~cm}^{-1} ;{ }^{1} \mathrm{H} \mathrm{NMR}\left(\mathrm{CDCl}_{3}\right)$ : $\delta 7.84(\mathrm{~s}, 1 \mathrm{H}, \mathrm{CH}=\mathrm{N}), 3.19,3.12\left(\mathrm{~m}, J_{\mathrm{H}-\mathrm{H}}=7.0 \mathrm{~Hz}, 2 \mathrm{H}, 2 \mathrm{H}\right.$, $\left.\mathrm{NCH}_{2} \mathrm{CH}_{3}\right), 1.83\left(\mathrm{~s}, 6 \mathrm{H}, \mathrm{C}\left(\mathrm{CH}_{3}\right)_{2}\right), 1.58\left(\mathrm{~s}, 9 \mathrm{H}, \mathrm{C}\left(\mathrm{CH}_{3}\right)_{3}\right), 1.43$ $\left(\mathrm{t}, J_{\mathrm{H}-\mathrm{H}}=7.0 \mathrm{~Hz}, 6 \mathrm{H}, \mathrm{NCH}_{2} \mathrm{CH}_{3}\right) ;{ }^{13} \mathrm{C} \mathrm{NMR}\left(\mathrm{CDCl}_{3}\right): \delta 177.0$ $(\mathrm{CH}=\mathrm{N}), 76.2\left(\mathrm{C}\left(\mathrm{CH}_{3}\right)_{2}\right), 50.2\left(\mathrm{NCH}_{2} \mathrm{CH}_{3}\right), 30.1\left(\mathrm{C}\left(\mathrm{CH}_{3}\right)_{3}\right), 29.6$ $\left(\mathrm{C}\left(\mathrm{CH}_{3}\right)_{3}\right), 22.1\left(\mathrm{C}\left(\mathrm{CH}_{3}\right)_{2}\right), 12.9\left(\mathrm{NCH}_{2} \mathrm{CH}_{3}\right) ; \mathrm{MS}(\mathrm{FAB}, \mathrm{m} / z)$ : $464.1\left(\mathrm{M}^{+}-\mathrm{Cl}\right)$.

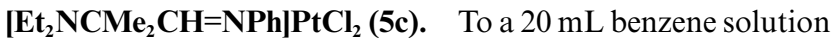
containing $(\mathrm{PhCN})_{2} \mathrm{PtCl}_{2}(50 \mathrm{mg}, 0.1 \mathrm{mmol})$ was added the ligand 2c $(125 \mathrm{mg}, 0.57 \mathrm{mmol})$. The solution was refluxed for $24 \mathrm{~h}$, then was concentrated. Addition of diethyl ether gave the yellow precipitate in $20 \%$ yield $(10 \mathrm{mg})$. Single crystals suitable for X-ray analysis were obtained by recrystallization from $\mathrm{CH}_{2} \mathrm{Cl}_{2}-\mathrm{Et}_{2} \mathrm{O} \cdot{ }^{1} \mathrm{H}$ $\mathrm{NMR}\left(\mathrm{CDCl}_{3}\right): \delta 8.13(\mathrm{~s}, 1 \mathrm{H}, \mathrm{CH}=\mathrm{N}), 7.37-7.08(\mathrm{~m}, 5 \mathrm{H}$, phenyl$H), 3.46,3.28\left(\mathrm{~m}, J_{\mathrm{H}-\mathrm{H}}=7.1 \mathrm{~Hz}, 2 \mathrm{H}, 2 \mathrm{H}, \mathrm{NCH}_{2} \mathrm{CH}_{3}\right), 1.81(\mathrm{~s}, 6 \mathrm{H}$, $\left.\mathrm{C}\left(\mathrm{CH}_{3}\right)_{2}\right), 1.52\left(\mathrm{t}, \mathrm{J}_{\mathrm{H}-\mathrm{H}}=7.1 \mathrm{~Hz}, 6 \mathrm{H}, \mathrm{NCH}_{2} \mathrm{CH}_{3}\right)$.

$\left[\mathbf{E t}_{\mathbf{2}} \mathbf{N C M e}_{2} \mathbf{C H}=\mathbf{N i} \mathbf{P r}\right] \mathbf{P d}(\mathrm{OAc})_{\mathbf{2}}(\mathbf{6 a})$. Treating a solution of $\mathbf{4 a}$ (144 mg, $0.398 \mathrm{mmol}$ ) in $15 \mathrm{~mL} \mathrm{CH} \mathrm{Cl}_{2}$ with $\mathrm{AgOAc}(133 \mathrm{mg}$, $0.797 \mathrm{mmol}$ ) under $\mathrm{N}_{2}$ atmosphere. The solution was stirred at $25{ }^{\circ} \mathrm{C}$ for $50 \mathrm{~min}$, then was concentrated after the removal of $\mathrm{AgCl}$ precipitates. Addition of diethyl ether gave the yellow solid product in $78 \%$ yield $(127 \mathrm{mg})$. IR (KBr): $v_{\mathrm{CO}}, v_{\mathrm{CN}} 1658,1626$, $1596 \mathrm{~cm}^{-1} ;{ }^{1} \mathrm{H}$ NMR $\left(\mathrm{CD}_{3} \mathrm{CN}, 200 \mathrm{MHz}\right): \delta 7.16(\mathrm{~s}, 1 \mathrm{H}, \mathrm{CH}=\mathrm{N})$, $3.61\left(\mathrm{~h}, J_{\mathrm{H}-\mathrm{H}}=6.6 \mathrm{~Hz}, 1 \mathrm{H}, \mathrm{CH}\left(\mathrm{CH}_{3}\right)_{2}\right), 2.97,2.72\left(\mathrm{qd}, \mathrm{qd}, J_{\mathrm{H}-\mathrm{H}}=\right.$ $\left.7.3 \mathrm{~Hz}, J_{\text {gem }}=12.6 \mathrm{~Hz}, 2 \mathrm{H}, 2 \mathrm{H}, \mathrm{NCH}_{2} \mathrm{CH}_{3}\right), 1.87,1.84(\mathrm{~s}, \mathrm{~s}, 3 \mathrm{H}$, $\left.3 \mathrm{H}, \mathrm{C}(\mathrm{O}) \mathrm{CH}_{3}\right), 1.83\left(\mathrm{~s}, 6 \mathrm{H}, \mathrm{C}\left(\mathrm{CH}_{3}\right)_{2}\right), 1.52\left(\mathrm{t}, J_{\mathrm{H}-\mathrm{H}}=7.1 \mathrm{~Hz}, 6 \mathrm{H}\right.$, $\left.\mathrm{NCH}_{2} \mathrm{CH}_{3}\right), 1.24\left(\mathrm{~d}, \mathrm{~J}_{\mathrm{H}-\mathrm{H}}=6.6 \mathrm{~Hz}, 6 \mathrm{H}, \mathrm{CH}\left(\mathrm{CH}_{3}\right)_{2}\right)$; $\mathrm{MS}(\mathrm{FAB}$, $m / z): 349.1\left(\mathrm{M}^{+}-\mathrm{OAc}\right)$.

$\left[\mathbf{E t}_{2} \mathbf{N C M e}_{2} \mathbf{C H}=\mathbf{N P h}\right] \mathbf{P d}(\mathbf{O A c})_{2} \quad(\mathbf{6 c})$. Using similar procedures as for $\mathbf{6 a}$, the reaction of $\mathbf{4 c}(141.7 \mathrm{mg}, 0.358 \mathrm{mmol})$ and AgOAc (119.6 mg, $0.717 \mathrm{mmol}$ ) gave the yellow precipitate of $\mathbf{6 c}$ in $95 \%$ yield $(150 \mathrm{mg})$. Single crystals were grown from $n$-hexane$\mathrm{MeOH}$ co-solvents. IR (KBr): $v_{\mathrm{CO}}, v_{\mathrm{CN}} 1631,1605,1579 \mathrm{~cm}^{-1} ;{ }^{1} \mathrm{H}$ NMR $\left(\mathrm{CD}_{3} \mathrm{CN}\right): \delta 7.41(\mathrm{~s}, 1 \mathrm{H}, \mathrm{CH}=\mathrm{N}), 7.29(\mathrm{br}, \mathrm{s}, 5 \mathrm{H}$, phenyl$H$ ), 3.13, 2.87 (qd, qd, $J_{\mathrm{H}-\mathrm{H}}=7.2 \mathrm{~Hz}, J_{\text {gem }}=13.0 \mathrm{~Hz}, 2 \mathrm{H}, 2 \mathrm{H}$, $\left.\mathrm{NCH}_{2} \mathrm{CH}_{3}\right), 1.97\left(\mathrm{~s}, 6 \mathrm{H}, \mathrm{C}\left(\mathrm{CH}_{3}\right)_{2}\right), 1.91\left(\mathrm{~s}, 3 \mathrm{H}, \mathrm{C}(\mathrm{O}) \mathrm{CH}_{3}\right), 1.63(\mathrm{t}$, $\left.J_{\mathrm{H}-\mathrm{H}}=7.2 \mathrm{~Hz}, 6 \mathrm{H}, \mathrm{NCH}_{2} \mathrm{CH}_{3}\right), 1.45\left(\mathrm{~s}, 3 \mathrm{H}, \mathrm{C}(\mathrm{O}) \mathrm{CH}_{3}\right) ;{ }^{13} \mathrm{C} \mathrm{NMR}$ $\left(\mathrm{CDCl}_{3}\right): \delta 179.5(C=\mathrm{O}), 177.8(C=\mathrm{N}), 145.2,128.9,122.5$ (phenyl-
C), $74.4\left(C\left(\mathrm{CH}_{3}\right)_{2}\right), 47.7\left(\mathrm{NCH}_{2} \mathrm{CH}_{3}\right), 23.3\left(\mathrm{C}\left(\mathrm{CH}_{3}\right)_{2}\right), 22.7,22.3$ $\left(\mathrm{C}(\mathrm{O}) \mathrm{CH}_{3}\right), 12.2\left(\mathrm{NCH}_{2} \mathrm{CH}_{3}\right)$; $\mathrm{MS}(\mathrm{FAB}, \mathrm{m} / z)$ : $382.1\left(\mathrm{M}^{+}-\mathrm{OAc}\right)$.

$\left[\mathbf{E t}_{2} \mathrm{NCMe}_{2} \mathbf{C H}=\mathbf{N}^{\mathrm{i}} \mathbf{P r}\right] \mathbf{P d}(\mathrm{Me}) \mathrm{Cl}$ (7a). To a $15 \mathrm{~mL} \mathrm{CH}_{2} \mathrm{Cl}_{2}$ solution containing (COD)Pd(Me)Cl (241.6 mg, $0.911 \mathrm{mmol})$ was added 2a $(176 \mathrm{mg}, 0.957 \mathrm{mmol})$. The solution was stirred at $25{ }^{\circ} \mathrm{C}$ for $1 \mathrm{~h}$, then concentrated. Addition of diethyl ether gave the yellow precipitate in $83 \%$ yield $(258 \mathrm{mg})$. Single crystals suitable for $\mathrm{X}$-ray analysis were obtained by recrystallization from $\mathrm{CH}_{2} \mathrm{Cl}_{2}-\mathrm{Et}_{2} \mathrm{O}$. IR (KBr pellet): $v_{\mathrm{CN}} 1646 \mathrm{~cm}^{-1} ;{ }^{1} \mathrm{H} \mathrm{NMR}\left(\mathrm{CDCl}_{3}\right)$ : $\delta 7.53(\mathrm{~s}, 1 \mathrm{H}, \mathrm{CH}=\mathrm{N}), 3.88\left(\mathrm{~h}, J_{\mathrm{H}-\mathrm{H}}=6.6 \mathrm{~Hz}, 1 \mathrm{H}, \mathrm{NCH}\left(\mathrm{CH}_{3}\right)_{2}\right)$, 2.91, $2.86\left(\mathrm{~m}, J_{\mathrm{H}-\mathrm{H}}=7.4,16.8 \mathrm{~Hz}, 4 \mathrm{H}, \mathrm{NCH}_{2} \mathrm{CH}_{3}\right), 1.56(\mathrm{~s}, 6 \mathrm{H}$, $\left.\mathrm{C}\left(\mathrm{CH}_{3}\right)_{2}\right), 1.26\left(\mathrm{dd}, J_{\mathrm{H}-\mathrm{H}}=7.4,7.4 \mathrm{~Hz}, 6 \mathrm{H}, \mathrm{NCH}_{2} \mathrm{CH}_{3}\right), 1.24(\mathrm{~d}$, $\left.J_{\mathrm{H}-\mathrm{H}}=6.6 \mathrm{~Hz}, 6 \mathrm{H}, \mathrm{NCH}\left(\mathrm{CH}_{3}\right)_{2}\right), 0.73\left(\mathrm{~s}, 3 \mathrm{H}, \mathrm{PdCH}_{3}\right) ;{ }^{13} \mathrm{C} \mathrm{NMR}$ $\left(\mathrm{CDCl}_{3}\right): \delta 176.6(\mathrm{C}=\mathrm{N}), 66.6\left(C\left(\mathrm{CH}_{3}\right)_{2}\right), 55.0\left(\mathrm{NCH}\left(\mathrm{CH}_{3}\right)_{2}\right), 43.8$ $\left(\mathrm{NCH}_{2} \mathrm{CH}_{3}\right), 23.4\left(\mathrm{C}\left(\mathrm{CH}_{3}\right)_{2}\right), 22.2\left(\mathrm{CH}\left(\mathrm{CH}_{3}\right)_{2}\right), 11.9\left(\mathrm{NCH}_{2} \mathrm{CH}_{3}\right)$, -4.48 $\left(\mathrm{PdCH}_{3}\right)$; $\mathrm{MS}(\mathrm{FAB}, \mathrm{m} / z)$ : $307.1\left(\mathrm{M}^{+}-\mathrm{Cl}\right)$. Anal. calcd for $\mathrm{C}_{12} \mathrm{H}_{27} \mathrm{ClN}_{2} \mathrm{Pd}$ : C, 42.24; H, 8.21; N, 7.98\%. Found: C, 42.22; H, $8.25 ; \mathrm{N}, 8.07 \%$.

$\left[\mathrm{Et}_{2} \mathrm{NCMe}_{2} \mathbf{C H}=\mathbf{N P h}\right] \mathbf{P d}(\mathrm{Me}) \mathrm{Cl}$ (7c). Using similar procedures as for $7 \mathbf{a}$, the reaction of (COD)Pd(Me)Cl (200 mg, 0.75 $\mathrm{mmol})$ and $2 \mathrm{c}(173 \mathrm{mg}, 0.79 \mathrm{mmol})$ gave the yellow precipitate of $7 \mathrm{c}$ in $68 \%$ yield $(620 \mathrm{mg})$. Alternatively, a reaction of $4 \mathbf{c}(86 \mathrm{mg}, 0.217$ $\mathrm{mmol}$ ) and $\mathrm{SnMe}_{4}(46 \mathrm{mg}, 0.257 \mathrm{mmol})$ was carried out in $\mathrm{CH}_{2} \mathrm{Cl}_{2}$ at $25{ }^{\circ} \mathrm{C}$ for $13 \mathrm{~h}$. After filtration with Celite the reaction solution was concentrated. Addition of diethyl ether gave the yellow solid product in $68 \%$ yield $(56 \mathrm{mg})$. Single crystals were grown from $\mathrm{CH}_{2} \mathrm{Cl}_{2}-\mathrm{Et}_{2} \mathrm{O}$ co-solvents. IR (KBr pellet): $v_{\mathrm{CN}} 1625 \mathrm{~cm}^{-1} ;{ }^{1} \mathrm{H}$ $\mathrm{NMR}\left(\mathrm{CDCl}_{3}\right): \delta 7.74(\mathrm{~s}, 1 \mathrm{H}, \mathrm{CH}=\mathrm{N}), 7.38-7.24,7.02-6.97(\mathrm{~m}$, $\left.\mathrm{m}, 3 \mathrm{H}, 2 \mathrm{H}, \mathrm{C}_{6} \mathrm{H}_{5}\right), 3.01,3.02\left(\mathrm{q}, J_{\mathrm{H}-\mathrm{H}}=7.3 \mathrm{~Hz}, 2 \mathrm{H}, \mathrm{NCH}_{2} \mathrm{CH}_{3}\right.$ ), $1.68\left(\mathrm{~s}, 6 \mathrm{H}, \mathrm{C}\left(\mathrm{CH}_{3}\right)_{2}\right), 1.33\left(\mathrm{t}, J_{\mathrm{H}-\mathrm{H}}=7.3 \mathrm{~Hz}, 6 \mathrm{H}, \mathrm{NCH}_{2} \mathrm{CH}_{3}\right)$, $0.46\left(\mathrm{~s}, 3 \mathrm{H}, \mathrm{PdCH} H_{3}\right) ;{ }^{13} \mathrm{C} \mathrm{NMR}\left(\mathrm{CDCl}_{3}\right): \delta 182.9(\mathrm{C}=\mathrm{N}), 147.8$, 129.0, 127.8, 122.1 (phenyl- $C$ ), $66.7\left(C\left(\mathrm{CH}_{3}\right)_{2}\right), 44.1\left(\mathrm{NCH}_{2} \mathrm{CH}_{3}\right)$, $23.3\left(\mathrm{C}\left(\mathrm{CH}_{3}\right)_{2}\right), 12.0\left(\mathrm{NCH}_{2} \mathrm{CH}_{3}\right), 0.80(\mathrm{PdCH})$; $\mathrm{MS}(\mathrm{FAB}, \mathrm{m} / z)$ : 323. $\left(\mathrm{M}^{+}-\mathrm{Cl}-\mathrm{CH}_{3}\right)$. Anal. calcd for $\mathrm{C}_{15} \mathrm{H}_{25} \mathrm{ClN}_{2} \mathrm{Pd}$ : $\mathrm{C}, 48.01 ; \mathrm{H}$, $6.71 ; \mathrm{N}, 7.47 \%$. Found: C, 47.84; H, 6.57; N, 7.75\%.

$\left\{\left[\mathbf{E t}_{2} \mathbf{N C M e}_{2} \mathbf{C H}=\mathbf{N}^{\mathrm{i}} \mathbf{P r}\right] \mathbf{P d}(\mathrm{Me})(\mathbf{N C M e})\right\}$ OTf (8a). 7a (50 mg, $0.147 \mathrm{mmol}$ ) was treated with AgOTf (38 $\mathrm{mg}, 0.148 \mathrm{mmol})$ in $\mathrm{CH}_{3} \mathrm{CN}$ for $15 \mathrm{~min}$, then $\mathrm{AgCl}$ precipitate was filtered off. The residue was a dark brown oil. ${ }^{1} \mathrm{H}$ NMR $\left(\mathrm{CDCl}_{3}\right): \delta 7.72(\mathrm{~s}, 1 \mathrm{H}$, $\mathrm{CH}=\mathrm{N}), 3.70\left(\mathrm{~h}, J_{\mathrm{H}-\mathrm{H}}=6.6 \mathrm{~Hz}, 1 \mathrm{H}, \mathrm{CH}\left(\mathrm{CH}_{3}\right)_{2}\right), 2.97,2.65(\mathrm{~m}$, $\left.J_{\mathrm{H}-\mathrm{H}}=7.0 \mathrm{~Hz}, J_{\text {gem }}=14.1 \mathrm{~Hz}, 2 \mathrm{H}, 2 \mathrm{H}, \mathrm{NCH}_{2} \mathrm{CH}_{3}\right), 2.38(\mathrm{~s}$, $\left.3 \mathrm{H}, \mathrm{NCCH}_{3}\right), 1.58\left(\mathrm{~s}, 6 \mathrm{H}, \mathrm{C}\left(\mathrm{CH}_{3}\right)_{2}\right), 1.27\left(\mathrm{t}, J_{\mathrm{H}-\mathrm{H}}=7.0 \mathrm{~Hz}, 6 \mathrm{H}\right.$, $\left.\mathrm{NCH}_{2} \mathrm{CH}_{3}\right), 1.19\left(\mathrm{~d}, J_{\mathrm{H}-\mathrm{H}}=6.6 \mathrm{~Hz}, 6 \mathrm{H}, \mathrm{CH}\left(\mathrm{CH}_{3}\right)_{2}\right), 0.63(\mathrm{~s}, 3 \mathrm{H}$, $\left.\mathrm{PdCH} H_{3}\right) ;{ }^{13} \mathrm{C}$ NMR $\left(\mathrm{CD}_{3} \mathrm{CN}\right): \delta 181.2(C=\mathrm{N}), 121(C \equiv \mathrm{N}), 67.9$ $\left(\mathrm{CCH}_{3}\right), 55.9\left(\mathrm{CH}\left(\mathrm{CH}_{3}\right)_{2}\right), 44.2\left(\mathrm{NCH}_{2} \mathrm{CH}_{3}\right), 23.1\left(\mathrm{C}\left(\mathrm{CH}_{3}\right)_{2}\right), 21.7$ $\left(\mathrm{CH}\left(\mathrm{CH}_{3}\right)_{2}\right), 11.7\left(\mathrm{NCH}_{2} \mathrm{CH}_{3}\right), 3.2\left(\mathrm{NCCH}_{3}\right),-0.7(\mathrm{PdCH}) ; \mathrm{MS}$ (FAB, $m / z): 346.1\left(\mathrm{M}^{+}-\mathrm{OTf}\right)$.

$\left\{\left[\mathrm{Et}_{2} \mathrm{NCMe}_{2} \mathrm{CH}=\mathbf{N P h}\right] \mathbf{P d}(\mathrm{Me})(\mathrm{NCMe})\right\}$ OTf (8c). $7 \mathrm{c}$ (166 mg, $0.44 \mathrm{mmol})$ was treated with AgOTf (114 mg, 0.444 $\mathrm{mmol}$ ) in $\mathrm{CH}_{3} \mathrm{CN}$ for $15 \mathrm{~min}$. The solution was filtered to remove the precipitate of $\mathrm{AgCl}$ and was concentrated. Addition of diethyl ether gave the yellow solid of $\mathbf{8 c}$ in $93 \%$ yield $(201 \mathrm{mg})$. Single crystals were grown from $\mathrm{CH}_{2} \mathrm{Cl}_{2}-\mathrm{Et}_{2} \mathrm{O}$ co-solvents. IR $(\mathrm{KBr}$ pellet): $v_{\mathrm{CN}} 1633 \mathrm{~cm}^{-1} ;{ }^{1} \mathrm{H} \mathrm{NMR}\left(\mathrm{CDCl}_{3}\right): \delta 7.97(\mathrm{~s}, 1 \mathrm{H}, \mathrm{CH}=\mathrm{N})$, 7.40-7.28, 7.05-7.01 (m, m, 3H, 2H, $\left.\mathrm{C}_{6} H_{5}\right), 3.13,2.87$ (m, m, $\left.J_{\mathrm{H}-\mathrm{H}}=7.1 \mathrm{~Hz}, J_{\mathrm{H}-\mathrm{H}}=7.1 \mathrm{~Hz}, 2 \mathrm{H}, \mathrm{NCH}_{2} \mathrm{CH}_{3}\right), 2.44(\mathrm{~s}, 3 \mathrm{H}$, $\left.\mathrm{NCCH}_{3}\right), 1.74\left(\mathrm{~s}, 6 \mathrm{H}, \mathrm{C}\left(\mathrm{CH}_{3}\right)_{2}\right), 1.37\left(\mathrm{t}, J_{\mathrm{H}-\mathrm{H}}=7.1 \mathrm{~Hz}, 6 \mathrm{H}\right.$, 
$\mathrm{NCH}_{2} \mathrm{CH}_{3}$ ), 0.44 (s, $\left.3 \mathrm{H}, \mathrm{PdCH}{ }_{3}\right) ;{ }^{13} \mathrm{C}$ NMR $\left(\mathrm{CDCl}_{3}\right): \delta 187.2$ $(C=\mathrm{N}), 146.5,129.3,128.5,122.3$ (phenyl- $C), 68.1\left(C\left(\mathrm{CH}_{3}\right)_{2}\right), 44.7$

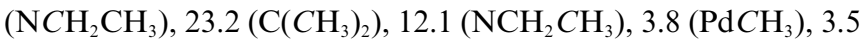
$\left(\mathrm{NCCH}_{3}\right)$; $\mathrm{MS}$ (FAB, $\left.m / z\right)$ : $380.1\left(\mathrm{M}^{+}-\mathrm{OTf}\right)$. Anal. calcd for $\mathrm{C}_{18} \mathrm{H}_{28} \mathrm{~F}_{3} \mathrm{~N}_{3} \mathrm{O}_{3} \mathrm{SPd}$ : C, 40.80; H, 5.33; N, 7.93\%. Found: C, 40.71; $\mathrm{H}, 5.26 ; \mathrm{N}, 7.70 \%$.

$\left[\mathrm{Et}_{2} \mathrm{NCMe}_{2} \mathbf{C H}=\mathrm{N}^{\mathrm{i}} \mathbf{P r}\right] \mathbf{P d C}(\mathrm{O}) \mathrm{MeCl}(\mathbf{9 a}) . \quad$ A $1 \mathrm{~mL}$ solution of $\mathrm{CDCl}_{3}$ containing $7 \mathrm{a}(31 \mathrm{mg}, 0.091 \mathrm{mmol})$ was bubbled with $\mathrm{CO}$ for $15 \mathrm{~min}$. The yellowish green solution was monitored with ${ }^{1} \mathrm{H}$ NMR: $\delta 7.52(\mathrm{~s}, 1 \mathrm{H}, \mathrm{C} H=\mathrm{N}), 3.66\left(\mathrm{~h}, J_{\mathrm{H}-\mathrm{H}}=6.4 \mathrm{~Hz}\right.$, $\left.1 \mathrm{H}, \mathrm{NCH}\left(\mathrm{CH}_{3}\right)_{2}\right), 2.78,2.64\left(\mathrm{~m}, J_{\text {н-н }}=7.2,14.5 \mathrm{~Hz}, 2 \mathrm{H}, 2 \mathrm{H}\right.$, $\left.\mathrm{NCH}_{2} \mathrm{CH}_{3}\right), 2.44$ (s, 3H, $\left.\mathrm{PdC}(\mathrm{O}) \mathrm{CH}_{3}\right), 1.53\left(\mathrm{~s}, 6 \mathrm{H}, \mathrm{C}\left(\mathrm{CH}_{3}\right)_{2}\right), 1.20$ $\left(\mathrm{t}, J_{\mathrm{H}-\mathrm{H}}=7.2 \mathrm{~Hz}, 6 \mathrm{H}, \mathrm{NCH}_{2} \mathrm{CH}_{3}\right), 1.15\left(\mathrm{~d}, J_{\mathrm{H}-\mathrm{H}}=6.4 \mathrm{~Hz}, 6 \mathrm{H}\right.$, $\left.\mathrm{NCH}\left(\mathrm{CH}_{3}\right)_{2}\right){ }^{13} \mathrm{C}$ NMR $\left(\mathrm{CDCl}_{3}\right): \delta 226.4(\mathrm{C}=\mathrm{O}), 176.8(\mathrm{C}=\mathrm{N})$, $65.5\left(\mathrm{C}_{\left.\left(\mathrm{CH}_{3}\right)_{2}\right),}\right), 0.0\left(\mathrm{NCH}\left(\mathrm{CH}_{3}\right)_{2}\right), 42.9 \quad\left(\mathrm{NCH}_{2} \mathrm{CH}_{3}\right), 36.0$ $\left(\mathrm{C}(\mathrm{O}) \mathrm{CH}_{3}\right), 23.6\left(\mathrm{C}\left(\mathrm{CH}_{3}\right)_{2}\right), 22.1\left(\mathrm{CH}\left(\mathrm{CH}_{3}\right)_{2}\right), 11.8\left(\mathrm{NCH}_{2} \mathrm{CH}_{3}\right)$; MS (FAB, $m / z): 333.0\left(\mathrm{M}^{+}-\mathrm{Cl}\right)$.

$\left[\mathbf{E t}_{2} \mathbf{N C M e}_{2} \mathbf{C H}=\mathbf{N P h}\right] \mathbf{P d C}(\mathbf{O}) \mathbf{M e C l}(\mathbf{9 c})$. To a $20 \mathrm{~mL} \mathrm{CH}_{2} \mathrm{Cl}_{2}$ containing $7 \mathrm{c}(254 \mathrm{mg}, 0.677 \mathrm{mmol})$, was bubbled with $\mathrm{CO}$ for $20 \mathrm{~min}$. The solution was concentrated. Addition of diethyl ether gave the yellow precipitate of $9 \mathbf{c}$ in $83 \%$ yield $(226 \mathrm{mg})$. IR ( $\mathrm{KBr}$ ): $v_{\mathrm{CN}} 1638 \mathrm{~cm}^{-1}, v_{\mathrm{CO}} 1716 \mathrm{~cm}^{-1} ;{ }^{1} \mathrm{H} \mathrm{NMR}\left(\mathrm{CDCl}_{3}\right): \delta 7.68(\mathrm{~s}, 1 \mathrm{H}$, $\mathrm{C} H=\mathrm{N}), 7.31-7.23,7.07-7.02\left(\mathrm{~m}, \mathrm{~m}, 3 \mathrm{H}, 2 \mathrm{H}, \mathrm{C}_{6} \mathrm{H}_{5}\right), 2.93-2.81(\mathrm{~m}$, $\left.J_{\mathrm{H}-\mathrm{H}}=7.3 \mathrm{~Hz}, 4 \mathrm{H}, \mathrm{NCH}_{2} \mathrm{CH}_{3}\right), 2.10\left(\mathrm{~s}, 3 \mathrm{H}, \mathrm{PdC}(\mathrm{O}) \mathrm{CH}_{3}\right), 1.66(\mathrm{~s}$, $\left.6 \mathrm{H}, \mathrm{C}\left(\mathrm{CH}_{3}\right)_{2}\right), 1.35\left(\mathrm{t}, J_{\mathrm{H}-\mathrm{H}}=7.3 \mathrm{~Hz}, 6 \mathrm{H}, \mathrm{NCH}_{2} \mathrm{CH}_{3}\right) ;{ }^{13} \mathrm{C} \mathrm{NMR}$ $\left(\mathrm{CDCl}_{3}\right): \delta 223.0(C=\mathrm{O}), 182.3(C=\mathrm{N}), 149.1,129.1,128.0,121.4$ (phenyl- $\mathrm{C}), 65.7\left(\mathrm{C}\left(\mathrm{CH}_{3}\right)_{2}\right), 43.4\left(\mathrm{NCH}_{2} \mathrm{CH}_{3}\right), 33.6\left(\mathrm{PdC}(\mathrm{O}) \mathrm{CH}_{3}\right)$, $23.5\left(\mathrm{C}\left(\mathrm{CH}_{3}\right)_{2}\right), 12.1 \quad\left(\mathrm{NCH}_{2} \mathrm{CH}_{3}\right) ; \mathrm{MS}(\mathrm{FAB}, \mathrm{m} / \mathrm{z}): 367.1$ $\left(\mathrm{M}^{+}-\mathrm{Cl}\right)$.

\section{$\left\{\left[\mathrm{Et}_{2} \mathrm{NCMe}_{2} \mathbf{C H}=\mathrm{N}^{\mathrm{i}} \mathrm{Pr}\right] \mathrm{Pd}\left[\mathrm{C}(\mathrm{O}) \mathrm{Me}\left(\mathrm{C}_{7} \mathrm{H}_{10}\right)\right]\right\}$ OTf}

(10a). Complex 9a was first prepared from $7 \mathbf{a}(113.6 \mathrm{mg}, 0.333 \mathrm{mmol})$ and $\mathrm{CO}$ in situ at $0{ }^{\circ} \mathrm{C}$. The reaction solution was flushed by nitrogen for $15 \mathrm{~min}$, followed by $2 \mathrm{~mL} \mathrm{CH} \mathrm{CH}_{3} \mathrm{CN}$, norbornene (nbe) $(31.5 \mathrm{mg}, 0.335 \mathrm{mmol})$, and AgOTf $(86 \mathrm{mg}, 0.335 \mathrm{mmol})$ in sequence. The solution was stirred at $0{ }^{\circ} \mathrm{C}$ for $3 \mathrm{~h}$. After removal of $\mathrm{AgCl}$ precipitate, the solution was concentrated. Addition of diethyl ether gave the whitish precipitate in $75 \%$ yield $(137 \mathrm{mg})$. IR $(\mathrm{KBr}): v_{\mathrm{CN}} 1643 \mathrm{~cm}^{-1}, v_{\mathrm{CO}} 1608 \mathrm{~cm}^{-1} ;{ }^{1} \mathrm{H}$ NMR $\left(\mathrm{CDCl}_{3}\right): \delta$ $7.87(\mathrm{~s}, 1 \mathrm{H}, \mathrm{CH}=\mathrm{N}), 3.62\left(\mathrm{~m}, 1 \mathrm{H}, \mathrm{NCH}\left(\mathrm{CH}_{3}\right)_{2}\right), 3.15,3.04,2.85$ (m, $1 \mathrm{H}, 1 \mathrm{H}, 1 \mathrm{H}, \mathrm{NCH}_{2} \mathrm{CH}_{3}+$ nbe), $2.68(\mathrm{br}, 1 \mathrm{H}, \mathrm{nbe}), 2.47$ (br, $2 \mathrm{H}$, nbe), $2.33\left(\mathrm{~m}, 4 \mathrm{H}\right.$, nbe and $\left.\mathrm{C}(\mathrm{O}) \mathrm{CH}_{3}\right), 1.96(\mathrm{br}, 1 \mathrm{H}, \mathrm{nbe})$, $1.82\left(\mathrm{~s}, 6 \mathrm{H}, \mathrm{C}\left(\mathrm{CH}_{3}\right)_{2}\right), 1.53$ (br, $3 \mathrm{H}, \mathrm{NCH}_{2} \mathrm{CH}_{3}+$ nbe), $1.40(\mathrm{br}$, $\left.3 \mathrm{H}, \mathrm{NCH}_{2} \mathrm{CH}_{3}\right), 1.34$ (br, $8 \mathrm{H}, \mathrm{NCH}\left(\mathrm{CH}_{3}\right)_{2}+$ nbe), 1.16 (br, $4 \mathrm{H}$, $\mathrm{NCH}_{2} \mathrm{CH}_{3}+$ nbe) ${ }_{1}^{13} \mathrm{C}$ NMR $\left(\mathrm{CDCl}_{3}\right): \delta 238,180.9,103.4,70.5$, 68.3, 57.8, 49.5, 44.6, 43.3, 43.2, 36.8, 29.5, 29.1, 27.3, 25.6, 24.0, 20.8, 20.6, 12.8, 10.7; MS (FAB, $m / z)$ : 427.1 (M+ - OTf). Anal. calcd for $\mathrm{C}_{21} \mathrm{H}_{37} \mathrm{~F}_{3} \mathrm{~N}_{2} \mathrm{O}_{4} \mathrm{SPd}$ : C, 43.71; H, 6.46; N, 4.85\%. Found: C, $42.71 ; \mathrm{H}, 6.28 ; \mathrm{N}, 4.92 \%$.

$\left\{\left[\mathrm{Et}_{2} \mathrm{NCMe}_{2} \mathrm{CH}=\mathrm{NPh}\right] \mathrm{Pd}\left[\mathrm{C}(\mathrm{O}) \mathrm{Me}\left(\mathrm{C}_{7} \mathrm{H}_{10}\right)\right]\right\}$ OTf (10c). Using similar procedures as for 10a, reaction of $7 \mathbf{c}(101 \mathrm{mg}, 0.269$ $\mathrm{mmol}$ ) gave the white solid $10 \mathrm{c}$ in $67 \%$ yield $(111 \mathrm{mg})$. The single crystals were grown by evaporating off $\mathrm{CHCl}_{3}$. IR $(\mathrm{KBr}): v_{\mathrm{CN}}$ $1624 \mathrm{~cm}^{-1}, v_{\mathrm{CO}} 1605 \mathrm{~cm}^{-1} ;{ }^{1} \mathrm{H}$ NMR $\left(\mathrm{CDCl}_{3}\right): \delta 8.02(\mathrm{~s}, 1 \mathrm{H}$, $\mathrm{C} H=\mathrm{N}), 7.38-7.18(\mathrm{~m}, 5 \mathrm{H}$, phenyl- $H), 3.24,3.12,3.02,2.73(\mathrm{~m}$, $\left.1 \mathrm{H}, 1 \mathrm{H}, 1 \mathrm{H}, 1 \mathrm{H}, \mathrm{NCH}_{2} \mathrm{CH}_{3}\right), 2.54,2.36\left(\mathrm{~d}, \mathrm{~d}, J_{\mathrm{H}-\mathrm{H}}=6.3 \mathrm{~Hz}\right.$, $\left.J_{\mathrm{H}-\mathrm{H}}=3.7 \mathrm{~Hz}, 1 \mathrm{H}, 1 \mathrm{H}, \mathrm{nbe}\right), 2.32\left(\mathrm{~s}, 3 \mathrm{H}, \mathrm{C}(\mathrm{O}) \mathrm{CH}_{3}\right), 2.07(\mathrm{dd}$, $\left.1 \mathrm{H}, J_{\mathrm{H}-\mathrm{H}}=6.3,2.1 \mathrm{~Hz}, \mathrm{nbe}\right), 1.67\left(\mathrm{~d}, J_{\mathrm{H}-\mathrm{H}}=10.3 \mathrm{~Hz}, 1 \mathrm{H}, \mathrm{nbe}\right)$, $1.92,1.64\left(\mathrm{~s}, \mathrm{~s}, 3 \mathrm{H}, 3 \mathrm{H}, \mathrm{C}\left(\mathrm{CH}_{3}\right)_{2}\right), 1.52,1,25\left(\mathrm{t}, \mathrm{t}, J_{\mathrm{H}-\mathrm{H}}=7.3 \mathrm{~Hz}\right.$, $\left.J_{\mathrm{H}-\mathrm{H}}=7.3 \mathrm{~Hz}, 3 \mathrm{H}, 3 \mathrm{H}, \mathrm{NCH}_{2} \mathrm{CH}_{3}\right), 1.44\left(\mathrm{tt}, J_{\mathrm{H}-\mathrm{H}}=12.4,4.6 \mathrm{~Hz}\right.$, $1 \mathrm{H}, \mathrm{nbe}), 1.33\left(\mathrm{~d}, J_{\mathrm{H}-\mathrm{H}}=3.7 \mathrm{~Hz}, 1 \mathrm{H}, \mathrm{nbe}\right), 1.12(\mathrm{~m}, 2 \mathrm{H}, \mathrm{nbe}), 0.85$ (tt, $\left.J_{\mathrm{H}-\mathrm{H}}=12.4,4.6 \mathrm{~Hz}, 1 \mathrm{H}, \mathrm{nbe}\right), 0.37(\mathrm{~m}, 1 \mathrm{H}, \mathrm{nbe}) ;{ }^{13} \mathrm{C} \mathrm{NMR}$ $\left(\mathrm{CDCl}_{3}\right): \delta 238.8(C=\mathrm{O}), 186.4(\mathrm{C}=\mathrm{N}), 146.9,129.1,128.4,122.5$ (phenyl-C), 70.7, 68.2, 53.3, 44.9, 43.9, 43.2, 42.1, 36.5, 29.2, 28.0, 27.3, 25.0, 21.1, 12.9, 11.2.

\section{X-Ray crystallographic analysis}

Diffraction data were measured on a Nonius CAD-4, SmartCCD, or Nonius KappaCCD diffractometer with graphitemonochromatized Mo $\mathrm{K} \alpha$ radiation $(\lambda=0.7103 \AA)$. No significant decay was observed during the data collection. The data were processed on a PC using the SHELXTL refinement software package. ${ }^{24}$ The structures were solved using the direct method and refined by full-matrix least-squares on the $F^{2}$ value.

All the non-hydrogen atoms were refined anisotropically. Hydrogen atoms were identified by calculation and refined using a riding mode, and their contributions to structure factors were included. Atomic scattering factors were taken from the International Tables of Crystallographic Data, Vol IV. ${ }^{25}$ Computing programs are from the NRC VAX package. Crystallographic data and selected atomic coordinates and bond parameters are collected in Tables 1-3. The rest of the data are supplied in the ESI.†

\section{Computational details}

All configurations were optimized by first using molecular mechanics MM+ (ArgusLab 4.01) and then with Amsterdam Density Functional (ADF 2004.01) without any restriction to symmetry and restrains. For the structures with crystallographic data, direct optimization was applied. The Vosko-Wilk-Nusair (VWN) parameterization of the electron gas for local density approximation (LDA) and exchange-correlation functionals from Becke-LeeYang-Parr (BLYP) for the generalized gradient approximation (GGA) were used. Relativistic zero-order regular approximation (ZORA) was applied.

For palladium, a standard triple-zeta Slater-type orbitals (STOs) basis set with one set of polarization functions was applied as implemented in the ADF basis set library (ADF database ZORA/TZP). The $1 \mathrm{~s}-4 \mathrm{p}$ electrons were treated with the frozen core approximation. For main-group elements $(\mathrm{C}, \mathrm{N}, \mathrm{O}, \mathrm{H})$ a standard double-zeta Slater-type orbitals (STOs) basis set with one set of polarization functions was applied as implemented in the ADF basis set library (ADF database ZORA/DZP). The $1 \mathrm{~s}$ electrons were treated with frozen core approximation. All structures shown correspond to minimum points on the potential surface. No symmetry constraints were used.

\section{Acknowledgements}

We thank the National Science Council, Taiwan, ROC, and the NSC-NWO joint project for the financial support.

\section{References}

1 (a) G. Helmghen and A. Pfaltz, Acc. Chem. Res., 2000, 33, 336345; (b) P. Kočovský, S. Vyskočil and M. Smrčina, Chem. Rev., 2003, 103, 3213-3245; (c) V. V. Grushin, Chem. Rev., 2004, 104, 1629-1662; (d) R. C. J. Atkinson, V. C. Gibson and N. J. Long, Chem. Soc. Rev., 
2004, 33, 313-328; (e) P. Braunstein, J. Organomet. Chem., 2004, 689, 3953-3967; ( $f$ ) G. Steiner, H. Kopacka, K.-H. Ongania, K. Wurst, P. Preishuber-Pflügl and B. Bildstein, Eur. J. Inorg. Chem., 2005, 13251333; (g) F. Speiser, P. Braunstein and L. Saussine, Acc. Chem. Res., 2005, 38, 784-793; (h) P. Braunstein, Chem. Rev., 2006, 106, 134-159; (i) P. Kuhn, D. Sémeril, D. Matt, M. J. Chetcuti and P. Lutz, Dalton Trans., 2007, 515-528; (j) O. Kühl, Chem. Soc. Rev., 2007, 36, 592-607.

2 (a) M. L. Creber, K. G. Orrell, A. G. Osborne, V. Šik, S. J. Coles, D. E. Hibbs and M. B. Hursthouse, Inorg. Chim. Acta, 2000, 299, 209-220; (b) M. W. van Laren, M. A. Duin, C. Klerk, M. Naglia, D. Rogolino, P. Pelagatti, A. Bacchi, C. Pelizzi and C. J. Elsevier, Organometallics, 2002, 21, 1546-1553; (c) L. P. Spencer, R. Altwer, P. Wei, L. Gelmini, J. Gauld and D. W. Stephan, Organometallics, 2003, 22, 3841-3854; (d) O. Kuhl and S. Blaurock, Inorg. Chem., 2004, 43, 6543-6545; (e) K. Nozaki, Chem. Rec., 2005, 5, 376-384; (f) M. Kettunen, C. Vedder, H.H. Brintzinger, I. Mutikainen, M. Leskelä and T. Repo, Eur. J. Inorg. Chem., 2005, 1081-1089; (g) A. Panella, J. Pons, J. García-Antón, X. Solans, M. F. Bardia and J. Ros, Inorg. Chim. Acta, 2006, 359, 23432349; (h) M. C. Torralba, M. Cano, J. A. Campo, J. V. Heras, E. Pinilla and M. R. Torres, J. Organomet. Chem., 2006, 691, 765-778; (i) S. Ito, K. Nishide and M. Yoshifuji, Organometallics, 2006, 25, 1424-1430; (j) C. Zhang, W.-H. Sun and Z.-X. Wang, Eur. J. Inorg. Chem., 2006, 48954902; (k) Y. Yang, S. Li, D. Cui, X. Chen and X. Jing, Organometallics, 2007, 26, 671-678; (l) Y. Yang, B. Liu, K. Lv, W. Gao, D. Cui, X. Chen and X. Jing, Organometallics, 2007, 26, 4575-4584; (m) Y.-T. Wang, G.-M. Tang and Z.-W. Qiang, Polyhedron, 2007, 26, 4542-4550.

3 (a) M. Kaupp, H. Stall, H. Preuss, W. Kahn, T. Stahl, G. Koten, E. Wissing, W. J. J. Smeets and A. L. Spek, J. Am. Chem. Soc., 1991, 113, 5606-5618; (b) D. S. Brown, A. Decken and A. H. Cowley, J. Am. Chem. Soc., 1995, 117, 5421-5422; (c) E. Wissing, S. van der Linden, E. Rijnberg, J. Boersma, W. J. J. Smeets, A. L. Spek and G. van Koten, Organometallics, 1994, 13, 2602-2608; (d) E. Wissing, E. Rijnberg, P. A. van der Schaaf, K. van Gorp, J. Boersma and G. van Koten, Organometallics, 1994, 13, 2609-2615; (e) A. Capapé, M. Crespo, J. Granell, M. Font-Bardía and X. Solans, J. Organomet. Chem., 2005, 690, 4309-4318; $(f)$ P. D. Waele, B. A. Jazdzewski, J. Klosin, R. E. Murray, C. N. Theriault, P. C. Vosejpka and J. L. Petersen, Organometallics, 2007, 26, 3896-3899.

4 (a) B. Y. Lee, G. C. Bazan, J. Vela, Z. J. A. Komon and X. Bu, J. Am. Chem. Soc., 2001, 123, 5352-5353; (b) J. A. Brito, M. Gómez, G. Muller, H. Teruel, J.-C. Clinet, E. Duňach and M. A. Maestro, Eur. J. Inorg. Chem., 2004, 4278-4285; (c) I. Favier, M. Gómez, J. Granell, M. Martínez, X. Solans and M. Font-Bardía, Dalton Trans., $2005,123$.

5 S. Blanchard, F. Neese, E. Bothe, E. Bill, T. Weyhermu1ller and K. Wieghardt, Inorg. Chem., 2005, 44, 3636-3656.

6 (a) V. X. Jin and J. D. Ranford, Inorg. Chim. Acta, 2000, 304, 38-44; (b) O. Yamauchi, A. Odani and M. Takani, J. Chem. Soc., Dalton Trans., 2002, 3411-3421; (c) T. Shoeib, K. W. M. Siu and A. C. Hopkinson, J. Phys. Chem. A, 2002, 106, 6121-6128; (d) J. M. Schveigkardt, A. C. Rizzi, O. E. Piro, E. E. Castellano, R. C. de Santana, R. Calvo and C. D. Brondino, Eur. J. Inorg. Chem., 2002, 2913-2919; (e) R. Dreos, G. Nardin, L. Randaccio, P. Siega and G. Tauzher, Inorg. Chem., 2004, 43, 3433-3440; (f) D. L. Stone, D. K. Smith and A. C. Whitwood, Polyhedron, 2004, 23, 1709-1717; (g) A. Habtemariam, M. Melchart, R. Fernández, S. Parsons, I. D. H. Oswald, A. Parkin, F. P. A. Fabbiani, J. E. Davidson, A. Dawson, R. E. Aird, D. I. Jodrell and P. J. Sadler, J. Med. Chem., 2006, 49, 6858-6868; (h) S. Novokmet, F. W. Heinemann, A. Zahl and R. Alsfasser, Inorg. Chem., 2005, 44, 47964805; (i) R. C. Santana, J. F. Carvalho, I. Vencato, H. B. Napolitano, A. J. Bortoluzzi, G. E. Barberis, R. E. Rapp, M. C. G. Passeggi and R. Calvo, Polyhedron, 2007, 26, 5001-5008.

7 (a) B. Y. Lee, X. Bu and G. C. Bazan, Organometallics, 2001, 20, 5425-5431; (b) M. Frøseth, A. Dhindsa, H. Røise and M. Tilset, Dalton Trans., 2003, 4516-4524; (c) J. C. Jenkins and M. Brookhart, Organometallics, 2003, 22, 250-256; (d) P. G. Hayes, G. C. Welch, D. J. H. Emslie, C. L. Noack, W. E. Piers and M. Parvez, Organometallics, 2003, 22, 1577-1579; (e) C. Bianchini, G. Mantovani, A. Meli, F. Migliacci, F. Zanobini, F. Laschi and A. Sommazzi, Eur. J. Inorg. Chem., 2003, 1620-1631; (f) P. Kolb, D. Demuth, J. M. Newsam, M. A. Smith, A. Sundermann, S. A. Schunk, S. Bettonville, J. Breulet and P. Francois, Macromol. Rapid Commun., 2004, 25, 280-285; (g) G. Steiner, H. Kopacka, K. H. Ongania, K. Wurst, P. Preishuber-Pflügl and B. Bildstein, Eur. J. Inorg. Chem., 2005, 13251333; (h) K. Nienkemper, V. V. Kotov, G. Kehr, G. Erker and R.
Fröhlich, Eur. J. Inorg. Chem., 2006, 366-379; (i) X. Liu, H. Xia, W. Gao, L. Ye, Y. Mu, Q. Su and Y. Ren, Eur. J. Inorg. Chem., 2006, 1216 1222 ; (j) Y. D. M. Champouret, J. Fawcett, W. J. Nodes, K. Singh and G. A. Solan, Inorg. Chem., 2006, 45, 9890-9900.

8 (a) M. L. Hlavinka and J. R. Hagadorn, Organometallics, 2005, 24, 4116-4118; (b) M. L. Hlavinka, M. J. McNevin, R. Shoemaker and J. R. Hagadorn, Inorg. Chem., 2006, 45, 1815-1822; (c) M. L. Hlavinka and J. R. Hagadorn, Organometallics, 2006, 25, 3501-3507; (d) J. Gómez, G. García-Herbosa, J. V. Cuevas, A. Arnáiz, A. Carbayo, A. Muňoz, L. Falvello and P. E. Fanwick, Inorg. Chem., 2006, 45, 2483-2493; (e) V. Diez, J. V. Cuevas, G. García-Herbosa, G. Aullón, J. P. H. Charmant, A. Carbayo and A. Muňoz, Inorg. Chem., 2007, 46, 568-577.

9 R. Bloch, Synthesis, 1978, 2, 140-142.

10 (a) M. P. Sibi, R. Zhang and S. Manyem, J. Am. Chem. Soc., 2003, 125, 9306-9307; (b) M. P. Sibi and L. M. Stanley, Tetrahedron: Asymmetry, 2004, 15, 3353-3356; (c) S. V. Larionov, A. V. Tkachev, Z. A. Savel'eva, L. I. Myachina, L. A. Glinskaya, R. F. Klevtsova and S. N. Bizyaev, Russ. J. Coord. Chem., 2006, 32, 250-260; (d) P. Camps, A. E. Lukach and R. A. Rossi, J. Org. Chem., 2001, 66, 5366-5373.

11 (a) Y. Fuchita, K. Yoshinaga, T. Hanaki, H. Hawano and J. KinoshitaNagaoka, J. Organomet. Chem., 1999, 580, 273-281; (b) A. G. Avent, P. B. Hichcock, G. J. Leigh and M. Togrou, J. Organomet. Chem., 2003, 669, 87-100; (c) S. Tsutsuminai, N. Komine, M. Hirano and S. Komiya, Organometallics, 2003, 22, 4238-4247; (d) A. M. Arink, C. M. P. Kronenburg, J. T. B. H. Jastrzebski, M. Lutz, A. L. Spek, R. A. Gossage and van G. Koten, J. Am. Chem. Soc., 2004, 126, 1624916258; (e) S. Tsutsuminai, N. Komine, M. Hirano and S. Komiya, Organometallics, 2004, 23, 44-53.

12 (a) R. F. Carina and A. F. Williams, Inorg. Chem., 2001, 40, 1826-1832; (b) S. Stoccoro, B. Soro, G. Minghetti, A. Zucca and M. A. Cinellu, J. Organomet. Chem., 2003, 679, 1-9.

13 (a) S. Stoccoro, G. Minghetti, M. A. Cinellu, A. Zucca and M. Manassero, Organometallics, 2001, 20, 4111-4113; (b) J. Setsune, T. Yamauchi, S. Tanikawa, Y. Hirose and J. Watanabe, Organometallics, 2004, 23, 6058-6065; (c) W. Liu and M. Brookhart, Organometallics, 2004, 23, 6099-6107; (d) R. Wang, B. Twamley and J. M. Shreeve, J. Org. Chem., 2006, 71, 426-429.

14 M. Schmid, R. Eberhardt, M. Klinga, M. Leskela and B. Rieger, Organometallics, 2001, 20, 2321-2330.

15 (a) J. S. Brumbaugh, R. R. Whittle, M. Parvez and A. Sen, Organometallics, 1990, 9, 1735-1747; (b) G. A. Luinstra and P. H. P. Brinkmann, Organometallics, 1998, 17, 5160-5165; (c) J. H. Groen, A. de Zwart, M. J. M. Vlaar, J. M. Ernsting, W. N. M. van Leeuwen, K. Vrieze, H. Kooijman, W. J. J. Smeets, A. L. Spek, P. H. M. Buszelaar, Q. Xiang and R. P. Thummel, Eur. J. Inorg. Chem., 1998, 1129-1143; (d) K. R. Reddy, K. Surekha, G.-H. Lee, S.-M. Peng, J.-T. Chen and S.-T. Liu, Organometallics, 2001, 20, 1292-1299; (e) M. Agostinho, P. Braunstein and R. Welter, Dalton Trans., 2007, 759-770.

16 (a) D. P. Gates, S. A. Svejda, E. Oňate, C. M. Killian, L. K. Johnson, P. S. White and M. Brookhart, Macromolecules, 2000, 33, 2320-2334; (b) H. S. Schrekker, V. Kotov, P. Preishuber-Pflugl, P. White and M. Brookhart, Macromolecules, 2006, 39, 6341-6354.

17 (a) R. E. Rülke, J. G. P. Delis, A. M. Groot, C. J. Elsevier, P. W. N. M. van Leeuwen, K. Vrieze, K. Goubitz and H. Schenk, J. Organomet. Chem., 1996, 508, 109-120; (b) D. H. Camacho, E. V. Salo, J. W. Ziller and Z. Guan, Angew. Chem., Int. Ed., 2004, 43, 1821.

18 (a) B. A. Markies, D. Kruis, M. H. P. Rietveld, K. A. N. Verkerk, J. Boersma, H. Kooijman, M. T. Lakin, A. L. Spek and G. ven Kotent, J. Am. Chem. Soc., 1995, 117, 5263; (b) J. G. P. Delis, P. G. Aubel, K. Vrieze and P. W. N. M. ven Leeuwen, Organometallics, 1997, 16, 4150; (c) A. D. Hennis, J. D. Polley, G. S. Long and A. Sen, Organometallics, 2001, 20, 2802; (d) M. Kang and A. Sen, Organometallics, 2004, 23, 5396.

19 (a) D. J. Tempel, L. K. Johnson, R. L. Huff, P. S. White and M. Brookhart, J. Am. Chem. Soc., 2000, 122, 6686; (b) N. M. Comerlato, G. L. Crossetti, R. A. Howie, P. C. D. Tibultinoa and J. L. Wardell, Acta Crystallogr., Sect. E: Struct. Rep. Online, 2001, 57, m295; (c) B. S. Williams, M. D. Leatherman, P. S. White and M. Brookhart, J. Am. Chem. Soc., 2005, 127, 5132.

20 (a) G. Anderson and R. J. Cross, Acc. Chem. Res., 1984, 17, 67-74; (b) G. P. C. M. Dekker, A. Buijs, C. J. Elsevier, K. Vrieze, P. W. N. M. van Leeuwen, W. J. J. Smeets, A. L. Spek, Y. F. Wang and C. H. Stam, Organometallics, 1992, 11, 1937.

21 R. Asselt, E. E. C. G. Gielens, R. E. Riilke, K. Vrieze and C. J. Elsevier, J. Am. Chem. Soc., 1994, 116, 911. 
22 (a) R. E. Riilke, J. G. P. Delis, A. M. Groot, C. J. Elsevier, P. W. N. M. van Leeuwen, K. Vrieze, K. Goubitz and H. Schenk, J. Organomet. Chem., 1996, 508, 109-120; (b) C. Gambs, G. Consiglio and A. Togni, Helv. Chim. Acta, 2001, 84, 3105-3126; (c) A. Bastero, A. Ruiz, C. Claver, B. Milani and E. Zangrando, Organometallics, 2002, 21, 5820-5829; (d) A. Bastero, C. Claver, A. Ruiz, S. Castillón, E. Daura, C. Bo and E. Zangrando, Chem.-Eur. J., 2004, 10, 3747-3760; (e) A. Leone, S. Gischig and G. Consiglio, J. Organomet. Chem., 2006, 691, 4816-4828.
23 (a) A. D. Burrows, M. F. Mahon and M. T. Palmer, J. Chem. Soc., Dalton Trans., 2000, 3615-3619; (b) S. L. Parisel, L. A. Adrio, A. A. Pereira, M. M. Pérez, J. M. Vila and K. K. Hii, Tetrahedron, 2005, 61, 9822-9826.

24 G. M. Sheldrick, SHELXTL-97, Program for solution of crystal structures, University of Göttingen, Germany, 1997.

25 D. T. Cromer and J. T. Waber, International Tables for X-ray Crystallography, The Kynoch Press, Birmingham, England, 1974, vol. IV. 